\title{
The Mechanism of Selective Separation of Antimony from Chloride Leachate of Copper Anode Slime
}

\author{
YANLIANG ZENG, CHUNFA LIAO*, ZHENGXIN XU, FUPENG LIU \\ Faculty of Metallurgy and Chemical Engineering, Jiangxi University of Science and Technology, Ganzhou 341000, China
}

Abstract: The mechanism of selective separation of antimony from copper anode slime leachate is studied. Density functional theory is used to calculate the unit cell energy, band structure, density of states, number of charge distributions and overlap populations of the $\mathrm{SbCl}_{3}$ hydrolysates $\mathrm{SbOCl}$, $\mathrm{Sb}_{3} \mathrm{O}_{4} \mathrm{Cl}$ and $\mathrm{Sb}_{4} \mathrm{O}_{5} \mathrm{Cl}_{2}$, and these are studied by infrared spectroscopy. The pathways for formation of $\mathrm{SbOCl}, \mathrm{Sb}_{3} \mathrm{O}_{4} \mathrm{Cl}$ and $\mathrm{Sb}_{4} \mathrm{O}_{5} \mathrm{Cl}_{2}$ in water, ethanol and ethylene glycol systems are clarified. The results show that the energy of the SbOCl unit cell is the lowest, and the structure is more stable. SbOCl exhibits strong electronic localization, weak orbital expansion, and more stability; SbOCl has a wider pseudoenergy gap, and its covalent bonds are stronger than those of $\mathrm{Sb}_{3} \mathrm{O}_{4} \mathrm{Cl}$ and $\mathrm{Sb}_{4} \mathrm{O}_{5} \mathrm{Cl}_{2}$. Hydrolysis of $\mathrm{SbCl}_{3}$ leads to preferential generation of more stable structures. The charge distribution, the sizes of overlap populations, and the infrared spectra indicate that $\mathrm{SbCl}_{3}$ has been hydrolysed. There are two basic paths for the process of alcoholysis: a water-or alcohol-ionized hydroxyl replaces one chlorine atom in $\mathrm{SbCl}_{3}$ to form an $\left[\mathrm{Sb}(\mathrm{OH}) \mathrm{Cl}_{2}\right]$ monomer, and as the degree of hydrolysis increases, the $\mathrm{H}$ and $\mathrm{Cl}$ atoms are removed to form $\mathrm{SbOCl}$. Conversely, $\mathrm{Sb}_{3} \mathrm{O}_{4} \mathrm{Cl}, \mathrm{Sb}_{4} \mathrm{O}_{5} \mathrm{Cl}_{2}$ or Sb atoms may be formed an [Sb-OH] monomer generated directly by water-or alcohol-ionised hydroxyl groups, and Cl atoms replace the $\mathrm{H}$ atom in the hydroxyl group of the [Sb-OH] monomer to form $\mathrm{SbOCl}, \mathrm{Sb}_{3} \mathrm{O}_{4} \mathrm{Cl}$ and $\mathrm{Sb}_{4} \mathrm{O}_{5} \mathrm{Cl}_{2}$.

Keywords: copper anode slime, antimony, density functional method, hydrolysis mechanism, infrared spectrum

\section{Introduction}

Copper anode slime is an important by product of the copper electrolytic refining process, and its yield accounts for approximately $0.2 \%-0.8 \%$ of the output of refined copper [1]. In 2019, China's copper anode slime output reached 78,000 t. Copper anode slime is rich in many rare and precious metals, such as gold, silver, selenium, tellurium, antimony, bismuth, and metals of the platinum group [1,2]. At present, there are many processes for treating copper anode slime to recover these valuable metals, such as the traditional pyrometallurgical process [3-5], a combined process of beneficiation and metallurgy $[3,5,6]$, the Kaldor furnace process [3,5], and a hydrometallurgical process [3,5,7]. Nevertheless, many problems still arise in these processes during industrial production, such as high energy consumption for pyrometallurgical processes, heavy pollution for combined processes, poor raw material applicability for Kaldor furnace processes, and difficult subsequent metal separation for hydrometallurgical processes. To recover valuable metals from anode slime in a more economical, efficient and environmentally-sound fashion, an innovative process was proposed and industrialized at Jiangxi Copper Co., Ltd. The process mainly includes "mixed acid leaching of bismuth and antimony separation of $\mathrm{Cu}$ by sulfated roasting followed by water leaching - sodium hydroxide leaching of tellurium - recovery and separation of gold and silver". In this process the following metals in the indicated proportions are effectively separated from copper anode slime: $>9-\% \mathrm{Bi}, 95 \% \mathrm{Sb}, 90 \% \mathrm{Se}$, 95\% Cu, 95\% Au and 96\% Ag. This shows that the process allows comprehensive recovery of valuable metals from copper anode slime. However, there are few reports on the mechanism of selective separation of valuable metals from copper anode slime. This makes it difficult to accurately control the metal separation process, which is not conducive to the stable operation of smelters.

$\overline{\text { *email:liaochfa@163.com }}$ 
In this proposed process, antimony is leached into solution by leaching with a mixed acid (sulfuric acid and hydrochloric acid). Then, antimony is hydrolysed to its oxychlorides by adjusting the $p \mathrm{H}$ of the leachate to achieve selective separation from other metal elements [8-10]. Although the separation of antimony can be carried out effectively at this stage, the hydrolysis mechanism of antimony needs further clarification.

The valence states of antimony are mainly +5 and +3 . Zheng et al. $[11,12]$ studied the hydrolysis process of $\mathrm{Sb}^{5+}$ and clarified that the initial hydrolysis product of $\mathrm{Sb}^{5+}$ was primarily amorphous antimony oxide, but with decreases of acidity and ageing time the hydrolysate changes from amorphous to crystalline. Tian et al. [13-19] carried out the hydrolysis of $\mathrm{Sb}^{3+}$ in a chloride salt system to probe aspects of the hydrolysis process such as equilibrium state, thermodynamics, kinetics, and hydrolysis products. The study clarified the mechanism for $\mathrm{Sb}^{3+}$ hydrolysis. Due to the difference in reaction conditions, operating methods, environmental conditions and other factors, the hydrolysis products of $\mathrm{Sb}^{3+}$ and $\mathrm{Sb}^{5+}$ were more complicated, and the amorphous and crystalline products were mixed. Therefore, the antimony hydrolysis process and mechanism were unclear and controversial, and the microstructure was not analysed.

Based on first principles and density functional theory, the reaction pathway of the hydrolysis process was studied by calculating the electronic structure, unit cell structure, energy band structure, density of states, charge layout number and overlapping population for $\mathrm{SbCl}_{3}, \mathrm{SbOCl}, \mathrm{Sb}_{3} \mathrm{O}_{4} \mathrm{Cl}$ and $\mathrm{Sb}_{4} \mathrm{O}_{5} \mathrm{Cl}_{2}$. Moreover, the oxidation state changes occurring during hydrolysis were further verified by infrared spectroscopy analysis.

\section{Materials and methods}

Using first-principles density functional theory (DFT) combined with the plane pseudopotential method, the CASTEP [20,21] module of MS software was used to optimize the unit cell structure and calculate the unit cell system energy and band structure of antimony compounds, as well as the total density of states and sub-state density, number of charge layouts, and number of overlapping clusters. The method established unit cell models for $\mathrm{SbCl}_{3}, \mathrm{SbOCl}, \mathrm{Sb}_{3} \mathrm{O}_{4} \mathrm{Cl}$, and $\mathrm{Sb}_{4} \mathrm{O}_{5} \mathrm{Cl}_{2}$ according to the relevant parameters in Table 1; the generalized gradient approximation (GGA) was used to correct the exchange effect from interactions between electrons in different unit cells; The Perdew-Burke-Ernzerh (PBE) in Generalized Gradient Approximation (GGA) was used to deal with interactions between electrons. The Monkhorst-Pack scheme was used to select the grid points in k-space and calculate the total energy and charge density of the system in the Brillouin zone. Brillouin zone $\mathrm{k}$ vectors were selected as $1 \times 2 \times 2,2 \times 2 \times 3,2 \times 4 \times 3$ and $3 \times 4 \times 1$; plane wave truncation energies were set to $244.9 \mathrm{eV}, 489.8 \mathrm{eV}$, $489.8 \mathrm{eV}$ and $489.8 \mathrm{eV}$, the self-consistent accuracy was set to $2.0 \times 10-6 \mathrm{eV} /$ atom, and the force acting on each atom did not exceed $0.05 \mathrm{eV} / \mathrm{nm}$.

Table 1. Unit cell parameters

\begin{tabular}{|c|c|c|c|c|c|c|c|}
\hline \multirow{2}{*}{ Title } & \multirow{2}{*}{$\begin{array}{c}\text { Space group } \\
\text { name }\end{array}$} & \multicolumn{6}{|c|}{ Lattice parameters } \\
\hline & & $a$ & $\mathrm{~b}$ & $\mathrm{c}$ & $\alpha$ & $\beta$ & $\gamma$ \\
\hline $\mathrm{SbCl}_{3}$ & $\mathrm{Pn} \mathrm{ma}$ & $8.11100 \AA$ & $9.41900 \AA$ & $6.31300 \AA$ & $90.0000^{\circ}$ & $90.0000^{\circ}$ & $90.0000^{\circ}$ \\
\hline $\mathrm{SbOCl}$ & $\mathrm{P} 21 / \mathrm{a}$ & $9.54000 \AA$ & $10.77000 \AA$ & $7.94000 \AA$ & $90.0000^{\circ}$ & $90.0000^{\circ}$ & $90.0000^{\circ}$ \\
\hline $\mathrm{Sb}_{3} \mathrm{O}_{4} \mathrm{Cl}$ & $\mathrm{P} 2 / \mathrm{c}$ & $9.65310 \AA$ & $5.30590 \AA$ & $5.59810 \AA$ & $90.0000^{\circ}$ & $94.7450^{\circ}$ & $90.0000^{\circ}$ \\
\hline $\mathrm{Sb}_{4} \mathrm{O}_{5} \mathrm{Cl}_{2}$ & $\mathrm{P} 21 / \mathrm{c}$ & $6.23800 \AA$ & $5.11120 \AA$ & $13.53800 \AA$ & $90.0000^{\circ}$ & $97.2170^{\circ}$ & $90.0000^{\circ}$ \\
\hline
\end{tabular}

Solid $\mathrm{SbCl}_{3}$ and a certain concentration of $\mathrm{SbCl}_{3}$ solution were used to carry out hydrolysis and alcoholysis reactions in different systems. $\mathrm{SbCl}_{3}$ solid powder was dissolved in hydrochloric acid to prepare a solution with concentrations of $0.05 \mathrm{~mol} / \mathrm{L} \mathrm{Sb}^{3+}$ and $1 \mathrm{~mol} / \mathrm{L} \mathrm{Cl}^{-}$, and this was added to equal volumes of deionized water, ethanol, and ethylene glycol. The reactions were stirred at room temperature $\left(25^{\circ} \mathrm{C}\right)$ for $2 \mathrm{~h}$, the $p \mathrm{H}$ values of the solutions were adjusted to 2 with aqueous ammonia, they were placed in an ultrasonic reactor for $1 \mathrm{~h}$, and the dry product was obtained by centrifugal filtration at $60^{\circ} \mathrm{C}$ for $6 \mathrm{~h}$. 
The filtrate was analysed by fourier infrared spectroscopy (FTIR-650, Tianjin Gangdong Technology Co., Ltd.).

\section{Results and discussions}

\subsection{First principles studies}

\subsubsection{Energy analysis}

The lower the total energy of the unit cell is, the more stable the structure of the unit cell [22-24]. The optimized structures and energies of $\mathrm{SbCl}_{3}, \mathrm{SbOCl}, \mathrm{Sb}_{3} \mathrm{O}_{4} \mathrm{Cl}$ and $\mathrm{Sb}_{4} \mathrm{O}_{5} \mathrm{Cl}_{2}$ were calculated, and the unit cell energy of each substance is shown in Table 2.

Table 2. Unit cell energy of each substance.

\begin{tabular}{|c|c|}
\hline Physical phase & Energy \\
\hline $\mathrm{SbCl}_{3}$ & $-14616.055 \mathrm{eV}$ \\
\hline $\mathrm{SbOCl}$ & $-38974.208 \mathrm{eV}$ \\
\hline $\mathrm{Sb}_{3} \mathrm{O}_{4} \mathrm{Cl}$ & $-18672.508 \mathrm{eV}$ \\
\hline $\mathrm{Sb}_{4} \mathrm{O}_{5} \mathrm{Cl}_{2}$ & $-25168.427 \mathrm{eV}$ \\
\hline
\end{tabular}

It can be seen from Table 2 that the $\mathrm{SbOCl}$ unit cell has the lowest energy. A preliminary analysis of the hydrolysis of $\mathrm{SbCl}_{3}$ suggests that priority will be given to the generation of $\mathrm{SbOCl}$, due to its low energy and stable structure.

\subsubsection{Energy band analysis}

The wider the energy band is, the greater the fluctuations, indicating that the effective mass of the electrons in the energy band is smaller, the extent of delocalization is greater, and the atomic orbitals that make up this energy band are more extended and more accessible for reactions. A narrow energy band width indicates that the eigenstate of the energy band is mainly composed of atomic orbitals at a certain lattice point in the local area. The electrons in this energy band are strongly localized, exhibiting limited orbital expansion and contributing to greater stability [25, 26].

The calculated energy band diagram for each substance is shown in Figure 1. This shows that the energy band of $\mathrm{SbCl}_{3}$ extends from $-28.5 \mathrm{eV}$ to $15.9 \mathrm{eV}$, so the bandwidth is $44.4 \mathrm{eV}$ and the band gap is $4.152 \mathrm{eV}$; the energy band of $\mathrm{SbOCl}$ extends from $-28.6 \mathrm{eV}$ to $16.4 \mathrm{eV}$, so the bandwidth is $45.0 \mathrm{eV}$ and the band gap width is $3.101 \mathrm{eV}$; the energy band of $\mathrm{Sb}_{3} \mathrm{O}_{4} \mathrm{Cl}$ extends from $-28.6 \mathrm{eV}$ to $17.8 \mathrm{eV}$, so the bandwidth is $46.4 \mathrm{eV}$ and the band gap is $2.737 \mathrm{eV}$; the energy band of $\mathrm{Sb}_{4} \mathrm{O}_{5} \mathrm{Cl}_{2}$ extends from -28.8 $\mathrm{eV}$ to $17.1 \mathrm{eV}$, so the bandwidth is $45.9 \mathrm{eV}$ and the band gap is $2.730 \mathrm{eV}$. By comparison, it can be seen that $\mathrm{SbOCl}$ has the narrowest energy band width and smallest fluctuations, indicating that electronic localization in the $\mathrm{SbOCl}$ energy band is very strong, orbital expansion is limited, the properties are relatively stable, the energy of the unit cell is consistent, and $\mathrm{SbOCl}$ more easily forms a stable structure.
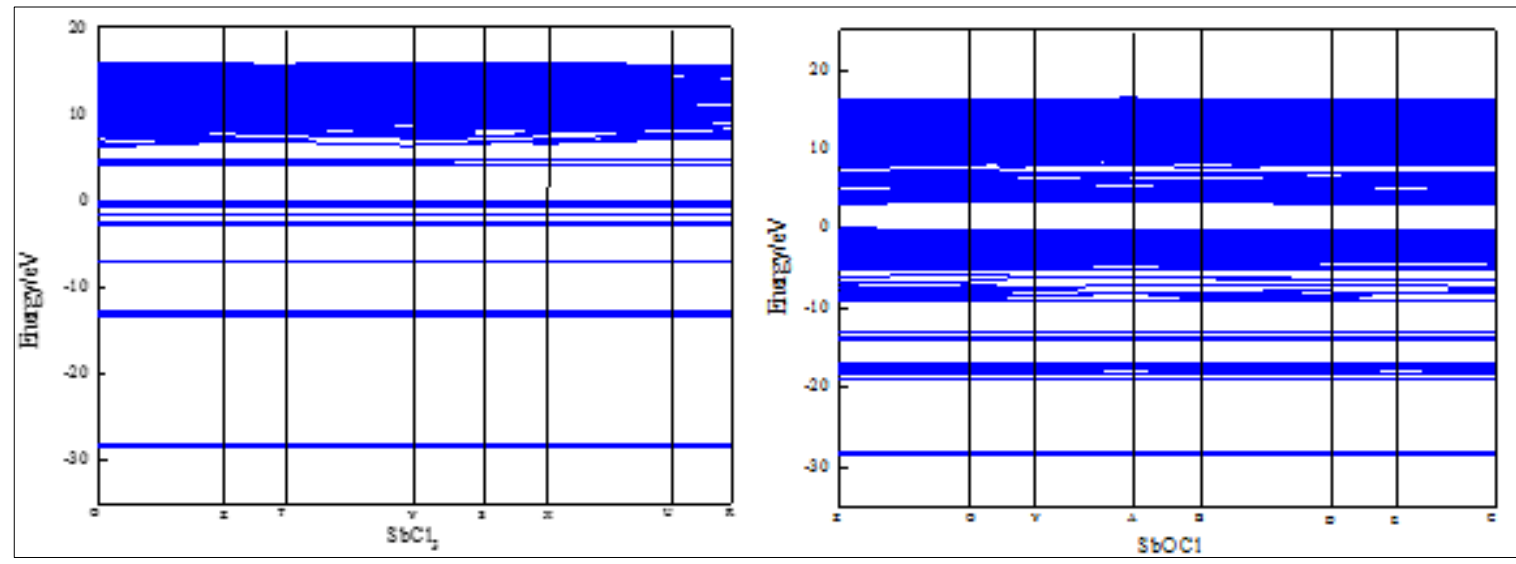

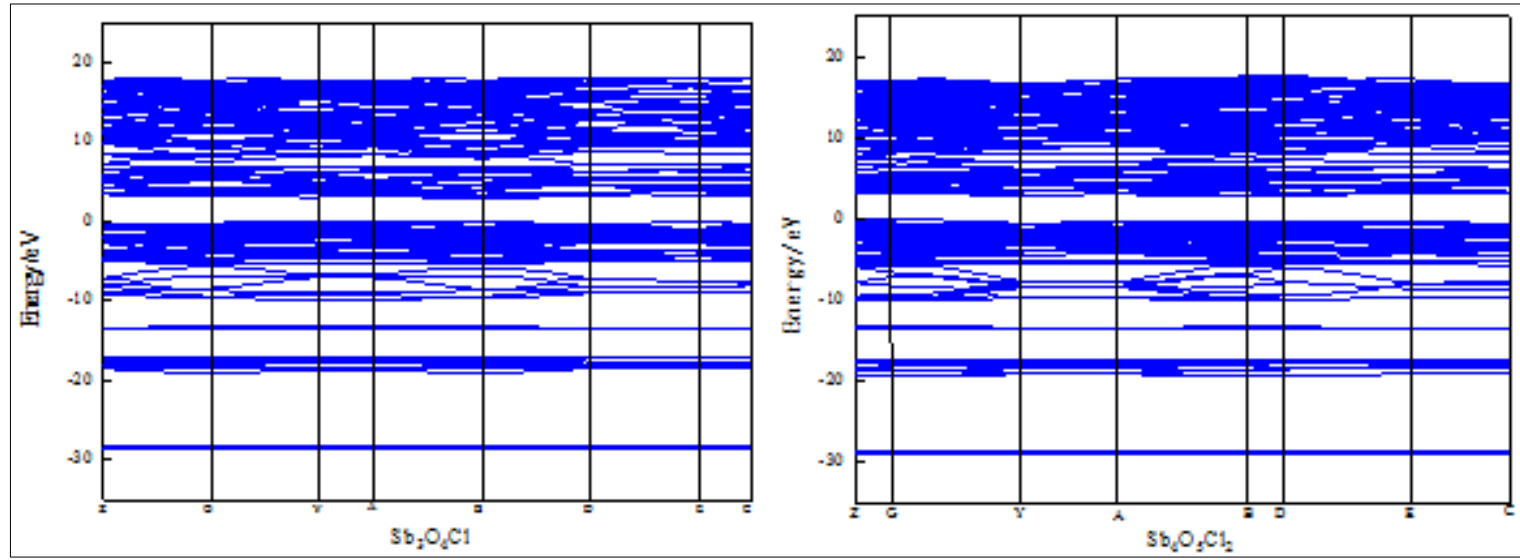

Figure 1. Energy bands of $\mathrm{SbCl}_{3}, \mathrm{SbOCl}, \mathrm{Sb}_{3} \mathrm{O}_{4} \mathrm{Cl}$ and $\mathrm{Sb}_{4} \mathrm{O}_{5} \mathrm{Cl}_{2}$

\subsubsection{Density analysis}

The size of the pseudoenergy gap in the density of states map (the peaks and valleys of the lowenergy bonding state and the high-energy antibonding region produce the pseudoenergy gap) reflects the strength of covalent bonding. The wider the pseudoenergy gap is, the greater the covalent character. The larger the abscissa of the peak density of states, the easier it is for extranuclear electrons to be distributed in the high-energy region, and the easier it is to remove electrons. In contrast, it is also easier to accept electrons $[27,28]$.

The calculated density of states diagram for each substance is shown in Figure 2. It can be seen that the pseudo-energy gap of $\mathrm{SbCl}_{3}$ extends from -0.386 to $4.290 \mathrm{eV}$ and the pseudo-energy gap is 4.676 $\mathrm{eV}$, which is mainly contributed by the electrons in $\mathrm{Cl} 2 \mathrm{p}$ and $\mathrm{Sb} 6 \mathrm{~s}$ and $6 \mathrm{p}$ orbitals; the pseudo-energy gap of $\mathrm{SbOCl}$ extends from -1.400 to $3.930 \mathrm{eV}$ and the pseudo-energy gap is $5.330 \mathrm{eV}$; the pseudoenergy gap of $\mathrm{Sb}_{3} \mathrm{O}_{4} \mathrm{Cl}$ extends from -0.393 to $3.610 \mathrm{eV}$ and the pseudo-energy gap is $4.003 \mathrm{eV}$; and the pseudo-energy gap of $\mathrm{Sb}_{4} \mathrm{O}_{5} \mathrm{Cl}_{2}$ extends from -0.524 to $3.500 \mathrm{eV}$ and the pseudo-energy gap is 4.024 $\mathrm{eV}$. Antimony oxychlorides are mainly contributed by electrons on the electron orbitals of $\mathrm{Cl} 2 \mathrm{p}, \mathrm{O} 2 \mathrm{p}$ and Sb6s6p. By comparison, it can be seen that the pseudoenergy gap of $\mathrm{SbOCl}$ is the largest, and the extent of covalent bonding among its atoms is the greatest. Therefore, the hydrolysis of $\mathrm{SbCl}_{3}$ more easily generates stable $\mathrm{SbOCl}$.
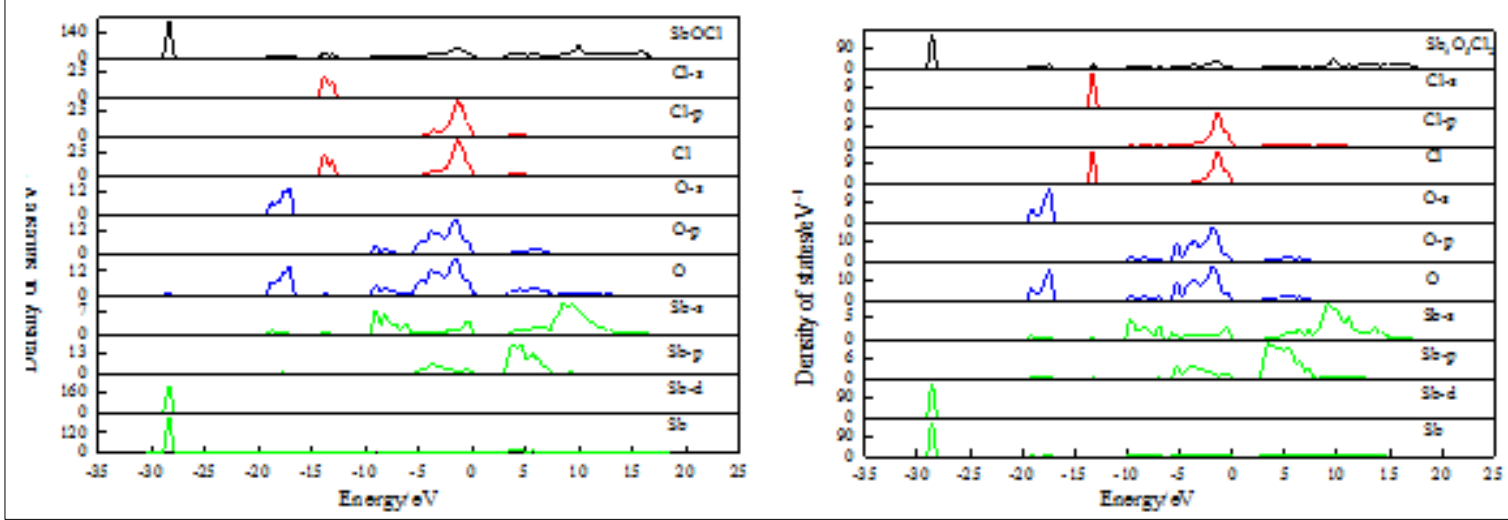

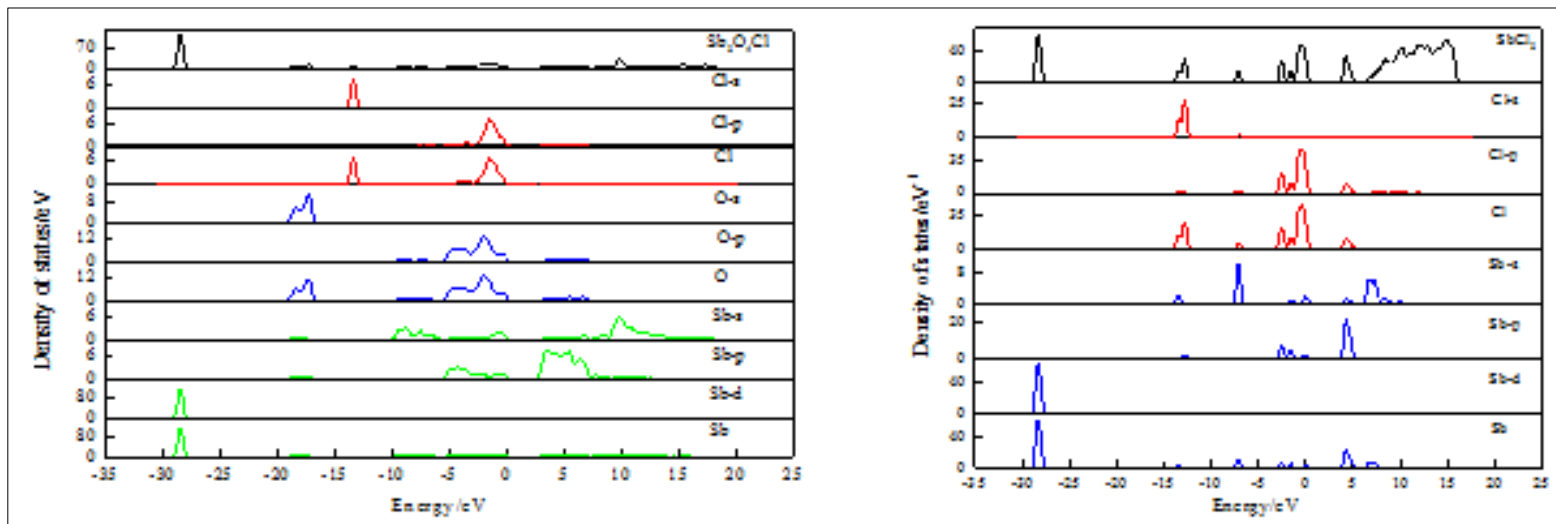

Figure 2. The state density and fractional state density of $\mathrm{SbCl}_{3}, \mathrm{SbOCl}, \mathrm{Sb}_{3} \mathrm{O}_{4} \mathrm{Cl}$, and $\mathrm{Sb}_{4} \mathrm{O}_{5} \mathrm{Cl}_{2}$

\subsubsection{The charge distribution number analysis}

The charge distribution number can reflect the gain or loss of electrons in an atom. A positive charge indicates a loss of electrons, and a negative charge indicates a gain of electrons. The gain and loss of electrons can strengthen the bonding interactions between atoms. The greater the number of electrons transferred, the stronger the bond interaction between atoms, and vice versa [29].

The calculated formal charge for each substance is shown in Table 3. It can be seen from Table 3 that the $\mathrm{SbCl}_{3}$ unit cell contains $12 \mathrm{Cl}$ atoms, and each $\mathrm{Cl}$ atoms contains 0.39 extra electrons; there are $4 \mathrm{Sb}$ atoms and each $\mathrm{Sb}$ atom has lost 1.17 electrons; Since all $\mathrm{Sb}$ atoms combined have lost 4.68 electrons, this matches the 0.39 electrons lost by each $\mathrm{Cl}$ atom.

From the formal charges of $\mathrm{SbOCl}$, it can be concluded that each of the $12 \mathrm{Sb}$ atoms has lost either $1.57,1.39$, or 1.37 electrons; the $12 \mathrm{O}$ atoms have all gained 0.97 electrons; there are $12 \mathrm{Cl}$ atoms and groups of $4 \mathrm{Cl}$ atoms each have received $0.43,0.42$, or 0.57 electrons. The greater the number of electrons transferred, the stronger the ionic bonding between atoms. Since oxygen atoms have gained more electrons than chlorine atoms, the $[\mathrm{Sb}-\mathrm{O}]$ ionic bond is stronger than the $[\mathrm{Sb}-\mathrm{Cl}]$ ionic bond. Based on this analysis, $\mathrm{SbOCl}$ can lose $\mathrm{Cl}$ atoms in the preparation of $\mathrm{Sb}_{2} \mathrm{O}_{3}$.

The formal charges of $\mathrm{Sb}_{3} \mathrm{O}_{4} \mathrm{Cl}$ show that among the $8 \mathrm{O}$ atoms, 4 receive 0.98 and 4 receive 0.97 electrons; the number of excess electrons in both $\mathrm{Cl}$ atoms is 0.56 ; the number of electrons lost by the 6 $\mathrm{Sb}$ atoms includes 4 atoms with a deficiency of 1.45 electrons and 2 atoms with a deficiency of 1.56 electrons. The $\mathrm{Sb}$ atoms that lose 1.45 electrons exist in the $\left[\mathrm{SbO}_{2}-\mathrm{O}-\mathrm{SbO}_{2}\right]$ unit; that is, the $2 \mathrm{Sb}$ atoms that lose 1.45 have lost a total of 2.9 electrons, and $2 \mathrm{O}$ atoms have received 0.97 electrons, and $1 \mathrm{O}$ atom received 0.98 electrons. The $\mathrm{Sb}$ atom that lost 1.56 electrons is bound to $1 \mathrm{Cl}$ atom with an excess of 0.56 electrons and $1 \mathrm{O}$ atom with an excess of 0.98 electrons. That is, the $\mathrm{Sb}-\mathrm{O}$ ionic bond within $\left[\mathrm{SbO}_{2}\right]$ units in $\left[\mathrm{SbO}_{2}-\mathrm{O}-\mathrm{SbO}_{2}\right]\left(\right.$ or $\left.\left[\mathrm{Sb}_{2} \mathrm{O}_{3}\right]\right)$ is stronger than the bonds to the bridging $\mathrm{O}$ atom shared by two $\left[\mathrm{SbO}_{2}\right]$ units in $\left[\mathrm{SbO}_{2}-\mathrm{O}-\mathrm{SbO}_{2}\right]$. Another antimony atom exists in the form of [SbOCl], where the $\mathrm{Sb}-\mathrm{O}$ bond is stronger than the $\mathrm{Sb}-\mathrm{Cl}$ bond.

From the formal charges of $\mathrm{Sb}_{4} \mathrm{O}_{5} \mathrm{Cl}_{2}$, it can be concluded that of the $10 \mathrm{O}$ atoms there are $4 \mathrm{O}$ atoms receiving 0.99 electrons, $4 \mathrm{O}$ atoms receiving 0.96 electrons and $2 \mathrm{O}$ atoms receiving 1.03 electrons; the number of electrons in $4 \mathrm{Cl}$ atoms is 0.57 ; the numbers of electrons lost by the $8 \mathrm{Sb}$ atoms include 1.51 (4 atoms) and 1.53 (4 atoms). An Sb atom that lost 1.45 electrons exists in the $\left[\mathrm{SbO}_{2} \mathrm{Cl}-\mathrm{O}-\mathrm{SbO}_{2} \mathrm{Cl}\right]$ unit; i.e., the $4 \mathrm{Sb}$ atoms that lost 1.51 elections provide a total loss of 6.04 electrons; $3 \mathrm{O}$ atoms each receive 0.96 electrons, $1 \mathrm{O}$ atom receives 0.99 electrons, $1 \mathrm{O}$ atom receives 1.03 electrons and $2 \mathrm{Cl}$ atoms each receive 0.57 electrons; $4 \mathrm{Sb}$ atoms each lose 1.53 electrons, for a total of 6.12 lost electrons; $1 \mathrm{O}$ atom receives 0.96 electrons, $3 \mathrm{O}$ atoms each receive 0.99 electrons, $1 \mathrm{O}$ atom receives 1.03 electrons and 2 $\mathrm{Cl}$ atoms each receive 0.57 electrons. That is, the $\mathrm{Sb}-\mathrm{O}$ ionic bond within $\left[\mathrm{Sb}_{2} \mathrm{O}_{2} \mathrm{Cl}\right]$ units in $\left[\mathrm{Sb}_{2} \mathrm{O}_{2} \mathrm{Cl}-\right.$ $\left.\mathrm{O}-\mathrm{Sb}_{2} \mathrm{O}_{2} \mathrm{Cl}\right]$ (or $\left[\mathrm{Sb}_{4} \mathrm{O}_{5} \mathrm{Cl}\right]$ ) is stronger than that in the $\mathrm{O}$ atom shared by two $\left[\mathrm{Sb}_{2} \mathrm{O}_{2} \mathrm{Cl}\right]$ units in $\left[\mathrm{Sb}_{2} \mathrm{O}_{2} \mathrm{Cl}-\mathrm{O}-\mathrm{Sb}_{2} \mathrm{O}_{2} \mathrm{Cl}\right]$. 
Table 3. Formal charge numbers

\begin{tabular}{|c|c|c|c|c|c|c|c|c|}
\hline Unit cell & Species & Ion & $\mathrm{s}$ & $\mathrm{p}$ & $\mathrm{d}$ & $\mathrm{f}$ & Total & Charge(e) \\
\hline \multirow{16}{*}{$\mathrm{SbCl}_{3}$} & $\mathrm{Cl}$ & 1 & 1.97 & 5.41 & 0.00 & 0.00 & 7.39 & -0.39 \\
\hline & $\mathrm{Cl}$ & 2 & 1.97 & 5.41 & 0.00 & 0.00 & 7.39 & -0.39 \\
\hline & $\mathrm{Cl}$ & 3 & 1.97 & 5.41 & 0.00 & 0.00 & 7.39 & -0.39 \\
\hline & $\mathrm{Cl}$ & 4 & 1.97 & 5.41 & 0.00 & 0.00 & 7.39 & -0.39 \\
\hline & $\mathrm{Cl}$ & 5 & 1.97 & 5.41 & 0.00 & 0.00 & 7.39 & -0.39 \\
\hline & $\mathrm{Cl}$ & 6 & 1.97 & 5.41 & 0.00 & 0.00 & 7.39 & -0.39 \\
\hline & $\mathrm{Cl}$ & 7 & 1.97 & 5.41 & 0.00 & 0.00 & 7.39 & -0.39 \\
\hline & $\mathrm{Cl}$ & 8 & 1.97 & 5.41 & 0.00 & 0.00 & 7.39 & -0.39 \\
\hline & $\mathrm{Cl}$ & 9 & 1.97 & 5.42 & 0.00 & 0.00 & 7.39 & -0.39 \\
\hline & $\mathrm{Cl}$ & 10 & 1.97 & 5.42 & 0.00 & 0.00 & 7.39 & -0.39 \\
\hline & $\mathrm{Cl}$ & 11 & 1.97 & 5.42 & 0.00 & 0.00 & 7.39 & -0.39 \\
\hline & $\mathrm{Cl}$ & 12 & 1.97 & 5.42 & 0.00 & 0.00 & 7.39 & -0.39 \\
\hline & $\mathrm{Sb}$ & 1 & 1.91 & 1.92 & 10.00 & 0.00 & 13.83 & 1.17 \\
\hline & $\mathrm{Sb}$ & 2 & 1.91 & 1.92 & 10.00 & 0.00 & 13.83 & 1.17 \\
\hline & $\mathrm{Sb}$ & 3 & 1.91 & 1.92 & 10.00 & 0.00 & 13.83 & 1.17 \\
\hline & $\mathrm{Sb}$ & 4 & 1.91 & 1.92 & 10.00 & 0.00 & 13.83 & 1.17 \\
\hline \multirow{19}{*}{$\mathrm{SbOCl}$} & $\mathrm{O}$ & 1 & 1.90 & 5.07 & 0.00 & 0.00 & 6.97 & -0.97 \\
\hline & $\mathrm{O}$ & $\frac{1}{2}$ & 1.90 & 5.07 & 0.00 & 0.00 & 6.97 & -0.97 \\
\hline & $\mathrm{O}$ & 3 & 1.90 & 5.07 & 0.00 & 0.00 & 6.97 & -0.97 \\
\hline & $\mathrm{O}$ & 4 & 1.90 & 5.07 & 0.00 & 0.00 & 6.97 & -0.97 \\
\hline & $\mathrm{O}$ & 5 & 1.90 & 5.07 & 0.00 & 0.00 & 6.97 & -0.97 \\
\hline & $\mathrm{O}$ & 6 & 1.90 & 5.07 & 0.00 & 0.00 & 6.97 & -0.97 \\
\hline & $\mathrm{O}$ & 7 & 1.90 & 5.07 & 0.00 & 0.00 & 6.97 & -0.97 \\
\hline & $\mathrm{O}$ & 8 & 1.90 & 5.07 & 0.00 & 0.00 & 6.97 & -0.97 \\
\hline & $\mathrm{O}$ & 9 & 1.90 & 5.07 & 0.00 & 0.00 & 6.97 & -0.97 \\
\hline & $\mathrm{O}$ & 10 & 1.90 & 5.07 & 0.00 & 0.00 & 6.97 & -0.97 \\
\hline & $\mathrm{O}$ & 11 & 1.90 & 5.07 & 0.00 & 0.00 & 6.97 & -0.97 \\
\hline & $\mathrm{O}$ & 12 & 1.90 & 5.07 & 0.00 & 0.00 & 6.97 & -0.97 \\
\hline & $\mathrm{Cl}$ & 1 & 1.97 & 5.46 & 0.00 & 0.00 & 7.43 & -0.43 \\
\hline & $\mathrm{Cl}$ & 2 & 1.97 & 5.46 & 0.00 & 0.00 & 7.42 & -0.42 \\
\hline & $\mathrm{Cl}$ & 3 & 1.97 & 5.60 & 0.00 & 0.00 & 7.57 & -0.57 \\
\hline & $\mathrm{Cl}$ & 4 & 1.97 & 5.46 & 0.00 & 0.00 & 7.43 & -0.43 \\
\hline & $\mathrm{Cl}$ & 5 & 1.97 & 5.46 & 0.00 & 0.00 & 7.42 & -0.42 \\
\hline & $\mathrm{Cl}$ & 6 & 1.97 & 5.60 & 0.00 & 0.00 & 7.57 & -0.57 \\
\hline & $\mathrm{Cl}$ & 7 & 1.97 & 5.46 & 0.00 & 0.00 & 7.43 & -0.43 \\
\hline \multirow{17}{*}{$\mathrm{SbOCl}$} & $\mathrm{Cl}$ & 8 & 1.97 & 5.46 & 0.00 & 0.00 & 7.42 & -0.42 \\
\hline & $\mathrm{Cl}$ & 9 & 1.97 & 5.60 & 0.00 & 0.00 & 7.57 & -0.57 \\
\hline & $\mathrm{Cl}$ & 10 & 1.97 & 5.46 & 0.00 & 0.00 & 7.43 & -0.43 \\
\hline & $\mathrm{Cl}$ & 11 & 1.97 & 5.46 & 0.00 & 0.00 & 7.42 & -0.42 \\
\hline & $\mathrm{Cl}$ & 12 & 1.97 & 5.60 & 0.00 & 0.00 & 7.57 & -0.57 \\
\hline & $\mathrm{Sb}$ & 1 & 1.77 & 1.66 & 10.00 & 0.00 & 13.43 & 1.57 \\
\hline & $\mathrm{Sb}$ & 2 & 1.83 & 1.77 & 10.00 & 0.00 & 13.61 & 1.39 \\
\hline & $\mathrm{Sb}$ & 3 & 1.86 & 1.76 & 10.00 & 0.00 & 13.63 & 1.37 \\
\hline & $\mathrm{Sb}$ & 4 & 1.77 & 1.66 & 10.00 & 0.00 & 13.43 & 1.57 \\
\hline & $\mathrm{Sb}$ & 5 & 1.83 & 1.77 & 10.00 & 0.00 & 13.61 & 1.39 \\
\hline & $\mathrm{Sb}$ & 6 & 1.86 & 1.76 & 10.00 & 0.00 & 13.63 & 1.37 \\
\hline & $\mathrm{Sb}$ & 7 & 1.77 & 1.66 & 10.00 & 0.00 & 13.43 & 1.57 \\
\hline & $\mathrm{Sb}$ & 8 & 1.83 & 1.77 & 10.00 & 0.00 & 13.61 & 1.39 \\
\hline & $\mathrm{Sb}$ & 9 & 1.86 & 1.76 & 10.00 & 0.00 & 13.63 & 1.37 \\
\hline & $\mathrm{Sb}$ & 10 & 1.77 & 1.66 & 10.00 & 0.00 & 13.43 & 1.57 \\
\hline & $\mathrm{Sb}$ & 11 & 1.83 & 1.77 & 10.00 & 0.00 & 13.61 & 1.39 \\
\hline & $\mathrm{Sb}$ & 12 & 1.86 & 1.76 & 10.00 & 0.00 & 13.63 & 1.37 \\
\hline \multirow{10}{*}{$\mathrm{Sb}_{3} \mathrm{O}_{4} \mathrm{Cl}$} & $\mathrm{O}$ & 1 & 1.90 & 5.07 & 0.00 & 0.00 & 6.97 & -0.97 \\
\hline & $\mathrm{O}$ & 2 & 1.90 & 5.08 & 0.00 & 0.00 & 6.98 & -0.98 \\
\hline & $\mathrm{O}$ & 3 & 1.90 & 5.07 & 0.00 & 0.00 & 6.97 & -0.97 \\
\hline & $\mathrm{O}$ & 4 & 1.90 & 5.08 & 0.00 & 0.00 & 6.98 & -0.98 \\
\hline & $\mathrm{O}$ & 5 & 1.90 & 5.07 & 0.00 & 0.00 & 6.97 & -0.97 \\
\hline & $\mathrm{O}$ & 6 & 1.90 & 5.08 & 0.00 & 0.00 & 6.98 & -0.98 \\
\hline & $\mathrm{O}$ & 7 & 1.90 & 5.07 & 0.00 & 0.00 & 6.97 & -0.97 \\
\hline & $\mathrm{O}$ & 8 & 1.90 & 5.08 & 0.00 & 0.00 & 6.98 & -0.98 \\
\hline & $\mathrm{Cl}$ & 1 & 1.96 & 5.60 & 0.00 & 0.00 & 7.56 & -0.56 \\
\hline & $\mathrm{Cl}$ & 2 & 1.96 & 5.60 & 0.00 & 0.00 & 7.56 & -0.56 \\
\hline
\end{tabular}




\begin{tabular}{|c|c|c|c|c|c|c|c|c|}
\hline & $\mathrm{Sb}$ & 1 & 1.82 & 1.73 & 10.00 & 0.00 & 13.55 & 1.45 \\
\hline & $\mathrm{Sb}$ & 2 & 1.82 & 1.73 & 10.00 & 0.00 & 13.55 & 1.45 \\
\hline & $\mathrm{Sb}$ & 3 & 1.82 & 1.73 & 10.00 & 0.00 & 13.55 & 1.45 \\
\hline & $\mathrm{Sb}$ & 4 & 1.82 & 1.73 & 10.00 & 0.00 & 13.55 & 1.45 \\
\hline & $\mathrm{Sb}$ & 5 & 1.80 & 1.63 & 10.00 & 0.00 & 13.44 & 1.56 \\
\hline & $\mathrm{Sb}$ & 6 & 1.80 & 1.63 & 10.00 & 0.00 & 13.44 & 1.56 \\
\hline \multirow{9}{*}{$\mathrm{Sb}_{4} \mathrm{O}_{5} \mathrm{Cl}_{2}$} & $\mathrm{O}$ & 1 & 1.90 & 5.09 & 0.00 & 0.00 & 6.99 & -0.99 \\
\hline & $\mathrm{O}$ & 2 & 1.89 & 5.07 & 0.00 & 0.00 & 6.96 & -0.96 \\
\hline & $\mathrm{O}$ & 3 & 1.90 & 5.09 & 0.00 & 0.00 & 6.99 & -0.99 \\
\hline & $\mathrm{O}$ & 4 & 1.89 & 5.07 & 0.00 & 0.00 & 6.96 & -0.96 \\
\hline & $\mathrm{O}$ & 5 & 1.90 & 5.09 & 0.00 & 0.00 & 6.99 & -0.99 \\
\hline & $\mathrm{O}$ & 6 & 1.89 & 5.07 & 0.00 & 0.00 & 6.96 & -0.96 \\
\hline & $\mathrm{O}$ & 7 & 1.90 & 5.09 & 0.00 & 0.00 & 6.99 & -0.99 \\
\hline & $\mathrm{O}$ & 8 & 1.89 & 5.07 & 0.00 & 0.00 & 6.96 & -0.96 \\
\hline & $\mathrm{O}$ & 9 & 1.86 & 5.17 & 0.00 & 0.00 & 7.03 & -1.03 \\
\hline \multirow{13}{*}{$\mathrm{Sb}_{4} \mathrm{O}_{5} \mathrm{Cl}_{2}$} & $\mathrm{O}$ & 10 & 1.86 & 5.17 & 0.00 & 0.00 & 7.03 & -1.03 \\
\hline & $\mathrm{Cl}$ & 1 & 1.97 & 5.60 & 0.00 & 0.00 & 7.57 & -0.57 \\
\hline & $\mathrm{Cl}$ & 2 & 1.97 & 5.60 & 0.00 & 0.00 & 7.57 & -0.57 \\
\hline & $\mathrm{Cl}$ & 3 & 1.97 & 5.60 & 0.00 & 0.00 & 7.57 & -0.57 \\
\hline & $\mathrm{Cl}$ & 4 & 1.97 & 5.60 & 0.00 & 0.00 & 7.57 & -0.57 \\
\hline & $\mathrm{Sb}$ & 1 & 1.81 & 1.66 & 10.00 & 0.00 & 13.47 & 1.53 \\
\hline & $\mathrm{Sb}$ & 2 & 1.79 & 1.70 & 10.00 & 0.00 & 13.49 & 1.51 \\
\hline & $\mathrm{Sb}$ & 3 & 1.81 & 1.66 & 10.00 & 0.00 & 13.47 & 1.53 \\
\hline & $\mathrm{Sb}$ & 4 & 1.79 & 1.70 & 10.00 & 0.00 & 13.49 & 1.51 \\
\hline & $\mathrm{Sb}$ & 5 & 1.81 & 1.66 & 10.00 & 0.00 & 13.47 & 1.53 \\
\hline & $\mathrm{Sb}$ & 6 & 1.79 & 1.70 & 10.00 & 0.00 & 13.49 & 1.51 \\
\hline & $\mathrm{Sb}$ & 7 & 1.81 & 1.66 & 10.00 & 0.00 & 13.47 & 1.53 \\
\hline & $\mathrm{Sb}$ & 8 & 1.79 & 1.70 & 10.00 & 0.00 & 13.49 & 1.51 \\
\hline
\end{tabular}

\subsubsection{Overlap population analysis}

The overlap population can be used to reflect the interaction between atoms, analyse the bonding properties between atoms and reflect the strength of bonds between atoms. The numbers for overlap populations are positive, which means that the atoms are bonded by covalent bonds. The larger the value is, the stronger the covalent bond and the more stable the unit cell structure; if the value for an overlap population is negative, it means that atoms are combined in the form of anti-bonds. The smaller the value, the stronger the repulsion between atoms and the weaker the stability; when the overlap population is 0 , there are ionic bonds between atoms [30-32]. The calculated overlap populations for each substance are shown in Table 4.

Table 4. Overlap population

\begin{tabular}{|c|c|c|c|c|c|c|c|c|c|}
\hline Unit cell & Bond & Population & Length(A) & Quantity & Unit cell & Bond & Population & Length(A) & Quantity \\
\hline \multirow{2}{*}{$\mathrm{SbCl}_{3}$} & $\mathrm{Cl}-\mathrm{Sb}$ & 0.29 & 2.40580 & 4 & \multirow{9}{*}{$\mathrm{Sb}_{3} \mathrm{O}_{4} \mathrm{Cl}$} & $\mathrm{O}-\mathrm{Sb}$ & 0.31 & 1.99466 & 4 \\
\hline & $\mathrm{Cl}-\mathrm{Sb}$ & 0.31 & 2.43414 & 8 & & $\mathrm{O}-\mathrm{Sb}$ & 0.32 & 2.00347 & 4 \\
\hline \multirow{10}{*}{$\mathrm{SbOCl}$} & $\mathrm{O}-\mathrm{Sb}$ & 0.38 & 1.97743 & 4 & & $\mathrm{O}-\mathrm{Sb}$ & 0.27 & 2.06080 & 4 \\
\hline & $\mathrm{O}-\mathrm{Sb}$ & 0.36 & 1.99155 & 4 & & $\mathrm{O}-\mathrm{Sb}$ & 0.18 & 2.12257 & 4 \\
\hline & $\mathrm{O}-\mathrm{Sb}$ & 0.29 & 2.02392 & 4 & & $\mathrm{O}-\mathrm{Sb}$ & 0.06 & 2.29521 & 4 \\
\hline & $\mathrm{O}-\mathrm{Sb}$ & 0.23 & 2.05346 & 4 & & $\mathrm{O}-\mathrm{O}$ & -0.06 & 2.69263 & 2 \\
\hline & $\mathrm{O}-\mathrm{Sb}$ & 0.22 & 2.08231 & 4 & & $\mathrm{O}-\mathrm{O}$ & -0.06 & 2.74405 & 4 \\
\hline & $\mathrm{O}-\mathrm{Sb}$ & 0.21 & 2.09117 & 4 & & $\mathrm{O}-\mathrm{O}$ & -0.08 & 2.90540 & 2 \\
\hline & $\mathrm{O}-\mathrm{Sb}$ & 0.07 & 2.25064 & 8 & & $\mathrm{O}-\mathrm{Sb}$ & -0.05 & 2.98789 & 4 \\
\hline & $\mathrm{Cl}-\mathrm{Sb}$ & 0.34 & 2.41302 & 4 & \multirow{11}{*}{$\mathrm{Sb}_{4} \mathrm{O}_{5} \mathrm{Cl}_{2}$} & $\mathrm{O}-\mathrm{Sb}$ & 0.36 & 1.93722 & 4 \\
\hline & $\mathrm{Cl}-\mathrm{Sb}$ & 0.31 & 2.43370 & 4 & & $\mathrm{O}-\mathrm{Sb}$ & 0.37 & 1.98900 & 4 \\
\hline & $\mathrm{O}-\mathrm{O}$ & -0.09 & 2.48546 & 2 & & $\mathrm{O}-\mathrm{Sb}$ & 0.23 & 2.05608 & 4 \\
\hline \multirow{8}{*}{$\mathrm{SbOCl}$} & $\mathrm{O}-\mathrm{O}$ & -0.09 & 2.54023 & 4 & & $\mathrm{O}-\mathrm{Sb}$ & 0.20 & 2.09237 & 4 \\
\hline & $\mathrm{O}-\mathrm{O}$ & -0.05 & 2.75230 & 4 & & $\mathrm{O}-\mathrm{Sb}$ & 0.18 & 2.11698 & 4 \\
\hline & $\mathrm{O}-\mathrm{O}$ & -0.03 & 2.95327 & 4 & & $\mathrm{O}-\mathrm{Sb}$ & 0.16 & 2.15594 & 4 \\
\hline & $\mathrm{Cl}-\mathrm{Sb}$ & -0.05 & 2.90635 & 4 & & $\mathrm{O}-\mathrm{O}$ & -0.09 & 2.51204 & 2 \\
\hline & & & & & & $\mathrm{O}-\mathrm{O}$ & 0.00 & 2.56141 & 4 \\
\hline & & & & & & $\mathrm{O}-\mathrm{O}$ & -0.07 & 2.61251 & 4 \\
\hline & & & & & & $\mathrm{O}-\mathrm{O}$ & -0.08 & 2.88777 & 4 \\
\hline & & & & & & $\mathrm{Cl}-\mathrm{Sb}$ & 0.13 & 2.93455 & 4 \\
\hline
\end{tabular}


We can see that the overlap populations of $\mathrm{SbCl}_{3}$ are both positive $(0.29$ and 0.31$)$, indicating that $\mathrm{Cl}$ and $\mathrm{Sb}$ atoms are connected by covalent bonds. The sums of the overlapping populations of $\mathrm{Sb}-\mathrm{Cl}$ bonds are 1.16 and 2.48 , respectively and the total is 3.64 ; the greater the population, the stronger the stability of the covalent bond; therefore, each $\left[\mathrm{SbCl}_{3}\right]$ unit contains one $\mathrm{Sb}-\mathrm{Cl}$ bond with an overlap population of 0.29 and two $\mathrm{Sb}-\mathrm{Cl}$ bonds with overlap populations of 0.31. Therefore, since 0.31>0.29, when $\mathrm{SbCl}_{3}$ is hydrolysed, the $\mathrm{OH}$ - produced by water ionization replaces a $\mathrm{Cl}$ atom from one of the $\mathrm{Sb}-\mathrm{Cl}$ bonds with an overlap population of 0.29 and forms $\mathrm{Sb}(\mathrm{OH}) \mathrm{Cl}_{2}$; subsequent loss of $\mathrm{HCl}$ leads to formation of $\mathrm{SbOCl}, \mathrm{Sb}_{3} \mathrm{O}_{4} \mathrm{Cl}$ and $\mathrm{Sb}_{4} \mathrm{O}_{5} \mathrm{Cl}_{2}$.

It can be seen from the list of $\mathrm{SbOCl}$ overlap populations that the overlap populations of $\mathrm{Sb}-\mathrm{O}$ bonds are all positive, with values of $0.38,0.36,0.29,0.23,0.22,0.21$ and 0.07 ; this indicates that $\mathrm{O}$ and $\mathrm{Sb}$ atoms are connected by covalent bonds. The sums of the overlap populations of Sb-O bonds are 1.52, $1.44,1.16,0.92,0.88,0.84$, and 0.56 , and the total is 7.32 . The overlap populations of $\mathrm{O}-\mathrm{O}$ bonds are all negative, with values of $-0.09,-0.05$ and -0.03 . This means that the $\mathrm{O}-\mathrm{O}$ bond includes an antibonding contribution, i.e., the two $\mathrm{O}$ atoms repel each other. The more negative the value is, the stronger the repulsive force between atoms and the lower the stability of the unit cell; the sums of the O-O bond overlap populations are $-0.54,-0.20$ and -0.12 , and the overall total is -0.86 . Cl-Sb bonds exhibit both positive and negative overlaps, indicating that $\mathrm{Cl}-\mathrm{Sb}$ bonds can include both covalent bonding and antibonding contributions. The positive overlap populations are 0.34 and 0.31 , the sums of these positive overlap populations are 1.36 and 1.24 , and the total is 2.60 . The negative overlap populations of $\mathrm{Cl}-\mathrm{Sb}$ bonds are -0.05 , and the sum of the negative overlap populations is -0.20 . It can be seen from the overlap populations of $\mathrm{SbOCl}$ that the stabilities of the $\mathrm{SbOCl}$ covalent bonds decrease in the order $\mathrm{Sb}-\mathrm{O}>\mathrm{Sb}$ $\mathrm{Cl}$ (positive) $>\mathrm{Sb}-\mathrm{Cl}$ (negative) $>\mathrm{O}-\mathrm{O}$.

From the overlap populations of $\mathrm{Sb}_{3} \mathrm{O}_{4} \mathrm{Cl}$, we can see that the overlap populations of $\mathrm{Sb}-\mathrm{O}$ bonds indicate the presence of covalent bonds and anti-bonds. The positive overlap populations of Sb-O bonds are $0.31,0.32,0.27,0.18$ and 0.06 , and the sums of the positive $\mathrm{Sb}-\mathrm{O}$ bond overlap populations are 1.24, $1.28,1.08,0.72$, and 0.24 , for a total of 4.56 ; another $\mathrm{Sb}-\mathrm{O}$ bond shows a negative overlap population with a value -0.05 , for a total of -0.20 . Finally, the overlap populations of $\mathrm{O}-\mathrm{O}$ bonds are -0.06 and 0.08 . The sums of the $\mathrm{O}-\mathrm{O}$ overlap populations are -0.36 and -0.16 , and the total is -0.52 , which means that the $\mathrm{O}-\mathrm{O}$ bonds exhibit antibonding interactions; the $2 \mathrm{O}$ atoms repel each other and the more negative value is, the stronger the repulsive force between atoms and the lower the stability of the unit cell. The overlap populations of $\mathrm{Sb}_{3} \mathrm{O}_{4} \mathrm{Cl}$ indicate that the stabilities of the covalent bonds in $\mathrm{Sb}_{3} \mathrm{O}_{4} \mathrm{Cl}$ decrease in the order $\mathrm{Sb}-\mathrm{O}>\mathrm{Sb}-\mathrm{O}($ Negative $)>\mathrm{O}-\mathrm{O}$.

The overlap populations of $\mathrm{Sb}_{4} \mathrm{O}_{5} \mathrm{Cl}_{2}$ show that the overlap populations of the $\mathrm{Sb}-\mathrm{O}$ bonds are all positive, with values of $0.36,0.37,0.23,0.20,0.18$, and 0.16 , which indicate that the $\mathrm{O}$ and $\mathrm{Sb}$ atoms are connected by covalent bonds. The sums of the overlap populations of Sb-O bonds are 1.44, 1.48, $0.92,0.80,0.72$, and 0.64 , and the total is 6.00 . The overlap populations of $\mathrm{O}-\mathrm{O}$ bonds are either negative or zero, indicating that both anti-bonds and ionic bonds are generated between $\mathrm{O}-\mathrm{O}$ bonds. They can form ionic bonds, and the negative overlap populations for antibonding interactions are $-0.09,-0.08$ and -0.07 , the sums of the overlap populations of $\mathrm{O}-\mathrm{O}$ bonds are $-0.18,-0.32$ and -0.28 , and the total is -0.78 . The overlap populations of $\mathrm{Cl}-\mathrm{Sb}$ bonds are all positive and exhibit values of 0.13 , indicating that $\mathrm{Cl}$ and $\mathrm{Sb}$ are connected by a covalent bond; The total number of overlapping clusters of $\mathrm{Sb}-\mathrm{O}$ bonds is 0.52. The overlap populations of $\mathrm{Sb}_{4} \mathrm{O}_{5} \mathrm{Cl}_{2}$ show that the stabilities of $\mathrm{Sb}_{4} \mathrm{O}_{5} \mathrm{Cl}_{2}$ covalent bond decrease in the order $\mathrm{Sb}-\mathrm{O}>\mathrm{Sb}-\mathrm{Cl}>\mathrm{O}-\mathrm{O}$ (negative) $>\mathrm{O}-\mathrm{O}$ (zero).

By comparing the overlap populations of $\mathrm{SbOCl}, \mathrm{Sb}_{3} \mathrm{O}_{4} \mathrm{Cl}$ and $\mathrm{Sb}_{4} \mathrm{O}_{5} \mathrm{Cl}_{2}$, it can be seen that the sum of the overlap populations in $\mathrm{SbOCl}$ covalent bonds is 9.92, the sum of the overlap populations for antibonding is -1.06 , the sum of overlap populations for covalent bonds and overlap populations of antibonding orbitals for the aggregate population is 8.86; therefore, the covalent bonding effect is 9.36 times that of the anti-bonding effect. The greater the covalent bonding contribution is, the more stable the structure $[33,34]$; the sum of the aggregated overlap populations for $\mathrm{Sb}_{3} \mathrm{O}_{4} \mathrm{Cl}$ covalent bonds is 4.56, the sum of the overlap populations for antibonding interactions is -0.72 , the overall sum of the overlap 
populations of both covalent bonding and antibonding is 3.84 , so the covalent bonding effect is 6.33 times the effect of antibonding. For $\mathrm{Sb}_{4} \mathrm{O}_{5} \mathrm{Cl}_{2}$, the sum of the overlap populations for covalent bonds is 6.52 , the sum of the overlap populations for antibonding is -0.78 , the overall sum is 5.74 , and the effect of covalent bonding is greater than that of anti-bonding. The covalent bond of $\mathrm{SbOCl}$ is the strongest, the force between atoms is the largest, and the stability of the unit cell is the highest. Therefore, the $\mathrm{Sb}(\mathrm{OH}) \mathrm{Cl}_{2}$ generated during the hydrolysis of $\mathrm{SbCl}_{3}$ more easily continues on to eliminate $\mathrm{HCl}$ and generate $\mathrm{SbOCl}$; that is, $\mathrm{SbOCl}$ is more stable than $\mathrm{Sb}_{4} \mathrm{O}_{5} \mathrm{Cl}_{2}$ or $\mathrm{Sb}_{3} \mathrm{O}_{4} \mathrm{Cl}$.

In summary, compared with $\mathrm{Sb}_{3} \mathrm{O}_{4} \mathrm{Cl}$ and $\mathrm{Sb}_{4} \mathrm{O}_{5} \mathrm{Cl}_{2}, \mathrm{SbOCl}$ has the lowest unit cell energy, the narrowest energy bandwidth and the widest pseudoenergy gap, i.e., the strongest covalent bonds between $\mathrm{Sb}, \mathrm{O}$ and $\mathrm{Cl}$ atoms. During the hydrolysis of $\mathrm{SbCl}_{3}$, it is easier to generate stable $\mathrm{SbOCl}$; from the formal charges, it can be seen that $\mathrm{SbCl}_{3}$ preferentially breaks the [Sb-Cl] bond with the weaker bond energy and forms $\mathrm{Sb}(\mathrm{OH}) \mathrm{Cl}_{2}$; among the group $\mathrm{SbOCl}, \mathrm{Sb}_{3} \mathrm{O}_{4} \mathrm{Cl}$ and $\mathrm{Sb}_{4} \mathrm{O}_{5} \mathrm{Cl}_{2}$, the [Sb-O] bond is stronger than the $[\mathrm{Sb}-\mathrm{Cl}]$ bond, and it is easy to remove the $\mathrm{Cl}$ atom in a later stage of the process to obtain $\mathrm{Sb}_{2} \mathrm{O}_{3}$ or $\mathrm{Sb}$ powder. By comparing the overlap populations for antibonding interactions and covalent bonds, it is seen that $\mathrm{SbOCl}$ is more stable than $\mathrm{Sb}_{4} \mathrm{O}_{5} \mathrm{Cl}_{2}$ and $\mathrm{Sb}_{3} \mathrm{O}_{4} \mathrm{Cl}$; that is, $\mathrm{Sb}(\mathrm{OH}) \mathrm{Cl}_{2}$ produced during the hydrolysis of $\mathrm{SbCl}_{3}$ can continue on to eliminate $\mathrm{HCl}$ and generate $\mathrm{SbOCl}$.

To further clarify whether the rupture and formation of covalent bonds during the hydrolysis of $\mathrm{SbCl}_{3}$ is consistent with the results of the calculation, infrared spectroscopy was used to analyse the hydrolysis of $\mathrm{SbCl}_{3}$ and the mechanism for formation of chlorine-oxygen covalent bonds.

\subsection{Hydrolysis mechanism for antimony chloride systems}

In the experiment, the filtrates from $\mathrm{SbCl}_{3}$ hydrolysis, ethanolysis, and glycolysis were analysed by infrared spectroscopy [35-41] to determine the reaction pathway for $\mathrm{SbCl}_{3}$ and the mechanism for replacement of chlorine by oxygen. The results are shown in Figure 3 and Figure 4. Characteristic infrared peaks are shown in Table 5.

Table 5. Infrared characteristic peaks

\begin{tabular}{|c|c|c|c|c|c|}
\hline Key types & $\mathrm{O}-\mathrm{H}$ & $\mathrm{C}-\mathrm{C}$ & Alcohol C-O & $-\mathrm{CH}_{3}$ & $-\mathrm{CH}_{2-}$ \\
\hline $\begin{array}{l}\text { Absorption } \\
\text { peak } \\
\text { position } \\
\left(\mathrm{cm}^{-1}\right)\end{array}$ & $\begin{array}{c}3350 \sim 3200 \\
(\text { Stretching ) } \\
\sim 1595 \text { (Bending) } \\
750 \sim 650 \text { (Out-of- } \\
\text { plane bending) }\end{array}$ & $400 \sim 900$ & 1260 1000 & $\begin{array}{c}\sim 2870 \\
(\text { Symmetric) } \\
\sim 2960 \\
\text { (Asymmetric) } \\
\sim 1380 \text { (Symmetric } \\
\text { deformation) }\end{array}$ & $\begin{array}{c}\sim 2925 \\
\text { (Asymmetric) } \\
\sim 2850 \\
\text { (Symmetric) } \\
1480 \sim 1440 \\
\text { (Scissor) }\end{array}$ \\
\hline
\end{tabular}

\subsubsection{Infrared spectroscopy of antimony oxychloride prepared by hydrolysis}

Figure 3 shows the infrared spectrum of the hydrolysis product from solid $\mathrm{SbCl}_{3}$. From $\mathrm{A}$ and $\mathrm{B}$ in Figure 3, it can be seen that the peak at $3313.21 \mathrm{~cm}^{-1}$ was due to the $\mathrm{O}-\mathrm{H}$ stretching vibration, and the peak at $1634.38 \mathrm{~cm}^{-1}$ was due to the $\mathrm{O}-\mathrm{H}$ intermolecular bending vibration. After adding $\mathrm{SbCl}_{3}$, the hydrolysis of $\mathrm{SbCl}_{3}$ facilitated the ionization of hydroxyl groups in water, the number of free hydroxyl groups in solution increased, and the concentration of hydroxyl groups was relatively increased. The $\mathrm{H}$ atom of $[\mathrm{H}-\mathrm{OH}]$ formed an $[\mathrm{Sb}-\mathrm{OH}]$ monomer. For $[\mathrm{Sb}-\mathrm{OH}]$, there is a hydrogen bond between the oxygen atom of the $-\mathrm{OH}$ in the monomer and a water molecule that is not easy to break. The electronegativity of chlorine is 3.16 , the electronegativity of hydrogen in water is 2.1 , and free $\mathrm{Cl}$ ions are produced in water. It is easy to replace the hydrogen atom in the hydroxyl group to form [Cl-O-Sb], that is, $\mathrm{SbOCl}$, since the $\mathrm{Sb}$ nucleus is larger than the $\mathrm{H}$ nucleus, and it is easy to form $\mathrm{Sb}[\mathrm{OH}]_{3}$ with the hydroxyl groups generated by ionisation of water. Because $\mathrm{Sb}[\mathrm{OH}]_{3}$ is unstable, it continued to hydrolyse to form $\mathrm{SbOCl}, \mathrm{Sb}_{3} \mathrm{O}_{4} \mathrm{Cl}$ and $\mathrm{Sb}_{4} \mathrm{O}_{5} \mathrm{Cl}_{2}$. $\mathrm{Cl}$ replaced the $\mathrm{H}$ atom in the water hydroxyl group so that the electron density increased, the force constant $\mathrm{k}$ increased, and an inductive effect was induced. The group frequency shifted to a higher wavenumber, the infrared spectrum of the water was redshift, 
and the electronegativity of the element increased. The stronger the inductive effect was, the more obvious the shift of the absorption peak to a higher wavenumber.

By comparing A and B in Figure 3, it can be seen that the absorption peak at $1634.38 \mathrm{~cm}^{-1}$ only shifted by $0.12 \mathrm{~cm}^{-1}$, while the absorption peak at $3331.21 \mathrm{~cm}^{-1}$ shifted by $2.39 \mathrm{~cm}^{-1}$; this clearly illustrates that the redshift of the absorption peak at $3313.21 \mathrm{~cm}^{-1}$ was not only due to the increased concentration of hydroxyl groups in solution but was also due to the inductive effect of the chlorine that replaced the hydrogen in the hydroxyl group.

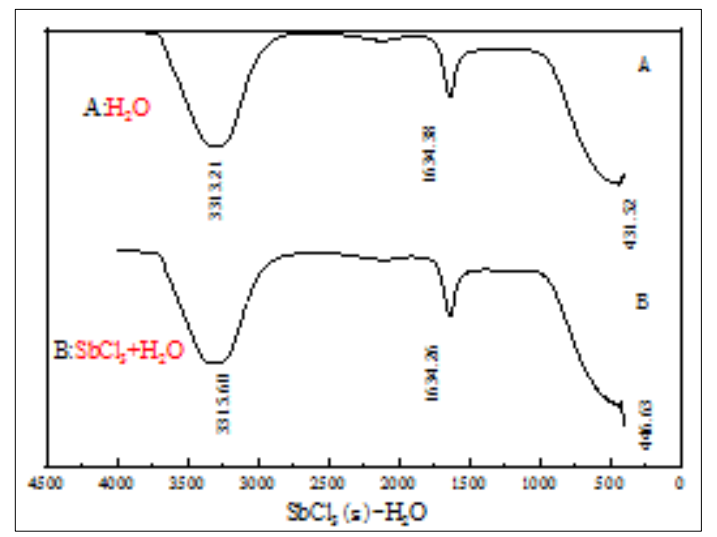

Figure 3. Infrared spectroscopy analysis of hydrolysis of $\mathrm{SbCl}_{3}$ solid $\left(\mathrm{A}-\mathrm{H}_{2} \mathrm{O} \quad \mathrm{B}-\mathrm{SbCl}_{3}+\mathrm{H}_{2} \mathrm{O}\right)$

\subsubsection{Infrared spectroscopy of antimony oxychloride prepared by alcoholysis in ethanol}

Figure 4 shows the infrared spectrum for the alcoholysis of $\mathrm{SbCl}_{3}$ solid in ethanol.

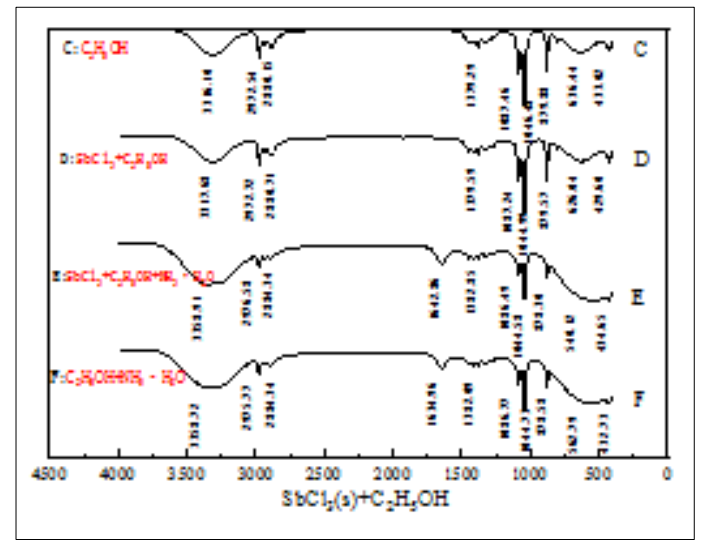

Figure 4. Infrared spectroscopy analysis of ethanol alcoholysis of solid $\mathrm{SbCl}_{3}$

\section{$\left(\mathrm{C}-\mathrm{C}_{2} \mathrm{H}_{5} \mathrm{OH}, \mathrm{D}-\mathrm{SbCl}_{3}+\mathrm{C}_{2} \mathrm{H}_{5} \mathrm{OH}, \quad \mathrm{E}-\mathrm{SbCl}_{3}+\mathrm{C}_{2} \mathrm{H}_{5} \mathrm{OH}+\mathrm{NH}_{3} \cdot \mathrm{H}_{2} \mathrm{O}, \quad \mathrm{F}-\mathrm{C}_{2} \mathrm{H}_{5} \mathrm{OH}+\mathrm{NH}_{3} \cdot \mathrm{H}_{2} \mathrm{O}\right)$}

It can be seen from line $\mathrm{C}$ in Figure 4 that the absorption peak at $3316.10 \mathrm{~cm}^{-1}$ was caused by an $\mathrm{OH}$ stretching vibration, the absorption peak at $2972.54 \mathrm{~cm}^{-1}$ was caused by a $-\mathrm{CH}$ asymmetric contraction vibration in $-\mathrm{CH}_{3}$, the peak at $2880.15 \mathrm{~cm}^{-1}$ was generated by the $-\mathrm{CH}$ symmetric contraction vibration in $-\mathrm{CH}_{3}$, the peak at $1379.29 \mathrm{~cm}^{-1}$ was generated by the $-\mathrm{CH}$ symmetric deformation vibration in $-\mathrm{CH}_{3}$, and the peak at $2880.15 \mathrm{~cm}^{-1}$ was generated by the symmetric stretch of $-\mathrm{CH}$ in $-\mathrm{CH}_{2}$. The $-\mathrm{CH}$ in $-\mathrm{CH}_{2}$ generated a peak at $1379.29 \mathrm{~cm}^{-1}$ due to shear vibration. The absorption peaks at $1087.46 \mathrm{~cm}^{-1}$ and $879.88 \mathrm{~cm}^{-1}$ were generated by $\mathrm{C}-\mathrm{C}$ bond stretch vibrations. The peak at $1046.48 \mathrm{~cm}^{-1}$ was caused by a $\mathrm{C}-\mathrm{O}$ stretching vibration, and the absorption peak at $636.44 \mathrm{~cm}^{-1}$ was caused by an $-\mathrm{OH}$ out-of-plane bending vibration. 
From the comparison between the $\mathrm{D}$ and $\mathrm{C}$ spectra in Figure 4, it can be seen that the absorption peak at $3316.10 \mathrm{~cm}^{-1}$ shifted by $1.58 \mathrm{~cm}^{-1}$, and the absorption peak at $636.44 \mathrm{~cm}^{-1}$ shifted by $10.4 \mathrm{~cm}^{-1}$ to low frequency. After the $\mathrm{H}$ on $-\mathrm{OH}$ was replaced by $\mathrm{Cl}$, the electron cloud density increased and the force constant $\mathrm{k}$ increased as a result of the inductive effect; therefore, the band at $3316.10 \mathrm{~cm}^{-1}$ shifted to a higher wavenumber, and the infrared spectrum of ethanol redshifted. The electronegativity of $\mathrm{Cl}$ (3.16) is greater than that of $\mathrm{H}(2.1)$. After $\mathrm{Cl}$ replaced the $\mathrm{H}$ on $-\mathrm{OH}$, a [C-O-Cl] monomer was formed. Since the electronegativity difference for the bonded atoms is greater, the absorption peak was stronger, the polarity was stronger, and the absorption peak was redshift; the weaker the polarity, the more the absorption peak was blueshift. Therefore, the polarity of $-\mathrm{OCl}$ is less than that of $-\mathrm{OH}$, so the absorption peak at $636.44 \mathrm{~cm}^{-1}$ shifted to lower frequency and a blueshift occurred, which proves that the $\mathrm{H}$ on $\mathrm{OH}$ was replaced by $\mathrm{Cl}$.

Since the alcoholysis of $\mathrm{SbCl}_{3}$ in ethanol was slow, the reaction was promoted by adding ammonia. By comparing lines $\mathrm{E}$ and $\mathrm{F}$ in Figure 4, we can see that the peak at $1634.96 \mathrm{~cm}^{-1}$ was caused by the stretching vibration of the $-\mathrm{NH}$ bond in $-\mathrm{NH}_{3}$, and the absorption peak at $3358.72 \mathrm{~cm}^{-1}$ redshift by 0.19 $\mathrm{cm}^{-1}$ and at $562.79 \mathrm{~cm}^{-1}$ blueshift. by $22.67 \mathrm{~cm}^{-1}$. That verifies the occurrence of an $\mathrm{SbCl}_{3}$ substitution reaction in ethanol.

\subsubsection{Infrared spectroscopy of antimony oxychloride prepared by glycolysis}

To further clarify the mechanism of the $\mathrm{SbCl}_{3}$ hydrolysis process, it was determined whether an alcoholysis reaction of $\mathrm{SbCl}_{3}$ would occur in ethylene glycol. The results show that the absorption peak at $3329.97 \mathrm{~cm}^{-1}$ in line $\mathrm{G}$ line was caused by an $-\mathrm{OH}$ stretching vibration, the absorption peaks at 2936.68 $\mathrm{cm}^{-1}$ and $2873.77 \mathrm{~cm}^{-1}$ were caused by $-\mathrm{CH}_{2}$ asymmetric and symmetric stretching, respectively, the $1408.20 \mathrm{~cm}^{-1}$ absorption peak was caused by a $-\mathrm{CH}_{2}$ bending vibration, the peak at $1204.06 \mathrm{~cm}^{-1}$ was caused by a C-C stretching vibration, the peaks at $1082.99 \mathrm{~cm}^{-1}$ and $1031.95 \mathrm{~cm}^{-1}$ were caused by C-O bond stretching vibrations, the peaks at $881.27 \mathrm{~cm}^{-1}$ and $860.18 \mathrm{~cm}^{-1}$ were produced by two -OH out-ofplane bending vibrations; since the vibrational frequency of the two $\left[\mathrm{CH}_{2} \mathrm{OH}\right]$ chemical bonds is the same, vibrational coupling occurred between them, causing the frequency of one of the peaks to be higher than the original frequency and the frequency of the other peak to be lower.

From a comparison of the $\mathrm{H}$ and $\mathrm{G}$ spectra in Figure 5, it can be seen that the band at $3329.97 \mathrm{~cm}^{-1}$ exhibited a shift of $9.99 \mathrm{~cm}^{-1}$ to lower frequency. This is because the electronegativity of $\mathrm{Cl}(3.16)$ is greater than that of $\mathrm{H}(2.1)$, and $\mathrm{Cl}$ replaces $-\mathrm{OH}$. After $\mathrm{H}$ loss, the formation of the $[\mathrm{C}-\mathrm{O}-\mathrm{Cl}]$ monomer occurred; the absorption peak at $881.27 \mathrm{~cm}^{-1}$ was redshift by $0.19 \mathrm{~cm}^{-1}$, and the absorption peak at 860.18 $\mathrm{cm}^{-1}$ was blueshift by $0.01 \mathrm{~cm}^{-1}$. One of the $-\mathrm{OH}$ groups in the alcohol was replaced by $\mathrm{Cl}$, and the other was not, resulting in an increase in the electron density of the substituted $-\mathrm{OH}$, an increase in the force constant $\mathrm{k}$, and an inductive effect causing the absorption at $881.27 \mathrm{~cm}^{-1}$ to redshift, while the absorption peak at $860.18 \mathrm{~cm}^{-1}$ was blueshift.

The alcoholysis reaction of solid $\mathrm{SbCl}_{3}$ was slow in ethylene glycol, so the reaction was promoted by adding ammonia water. By comparing lines $\mathrm{I}$ and $\mathrm{J}$ in Figure 5, it can be seen that the peak at 1643.32 $\mathrm{cm}^{-1}$ was caused by the stretching vibration of the $-\mathrm{NH}$ bond in $\mathrm{NH}_{3}$. There are absorption peaks at $3284.52 \mathrm{~cm}^{-1}, 882.33 \mathrm{~cm}^{-1}$ and $860.99 \mathrm{~cm}^{-1}$ and the absorption peak at $3284.52 \mathrm{~cm}^{-1}$ was blueshift by $4.88 \mathrm{~cm}^{-1}$, the peak at $882.33 \mathrm{~cm}^{-1}$ was blueshift by $0.33 \mathrm{~cm}^{-1}$, and the peak at $860.99 \mathrm{~cm}^{-1}$ was redshift by $0.33 \mathrm{~cm}^{-1}$, further verifying that the substitution of $\mathrm{SbCl}_{3}$ occurred in ethylene glycol. 


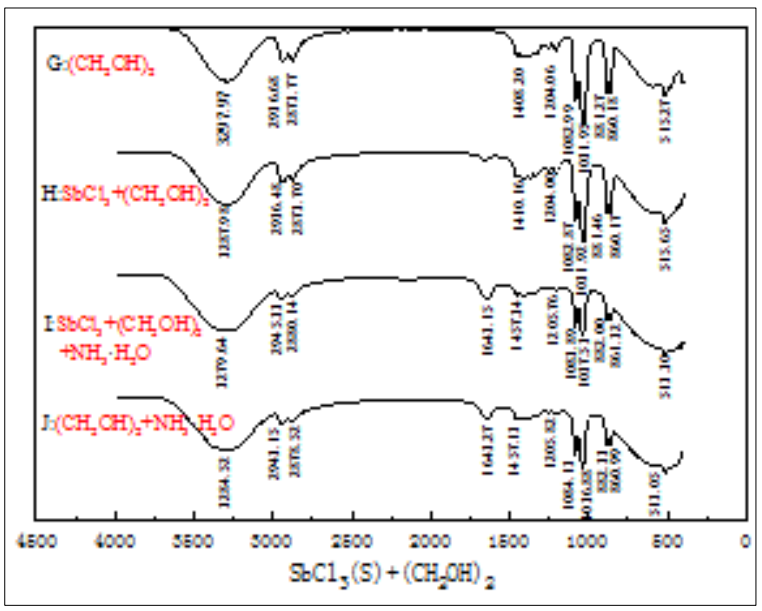

Figure 5. Infrared spectroscopy analysis of glycol alcoholysis of $\mathrm{SbCl}_{3}$ solid.

$\left(\mathrm{G}-\left(\mathrm{CH}_{2} \mathrm{OH}\right)_{2} \quad \mathrm{H}-\mathrm{SbCl}_{3}+\left(\mathrm{CH}_{2} \mathrm{OH}\right)_{2}\right.$

$\mathrm{I}-\mathrm{SbCl}_{3}+\left(\mathrm{CH}_{2} \mathrm{OH}\right)_{2}+\mathrm{NH}_{3} \cdot \mathrm{H}_{2} \mathrm{O}$ $\left.\mathrm{J}-\left(\mathrm{CH}_{2} \mathrm{OH}\right)_{2}+\mathrm{NH}_{3} \cdot \mathrm{H}_{2} \mathrm{O}\right)$

\subsubsection{Hydrolysis mechanism of antimony in the $\mathrm{Sb}^{3+}-\mathrm{HCl}$ system}

To verify whether the hydrolysis, alcoholysis, and glycolysis of solid $\mathrm{SbCl}_{3}$ were consistent with the $\mathrm{Sb}^{3+}$ hydrolysis process occurring in aqueous solution, $\mathrm{SbCl}_{3}$ solutions with concentrations of $0.05 \mathrm{~mol} / \mathrm{L}$ $\mathrm{Sb}^{3+}$ and $1 \mathrm{~mol} / \mathrm{L} \mathrm{Cl}^{-}$were prepared for studies of hydrolysis and alcoholysis. The reactions were carried out under the same conditions, and the products were analysed by infrared spectroscopy. The results are shown in Figure 6. By comparison, it was found that the infrared spectrum was completely consistent with that from the reaction of solid $\mathrm{SbCl}_{3}$, which confirms the mechanism of the $\mathrm{SbCl}_{3}$ hydrolysis process. There are two main ways to hydrolyse $\mathrm{SbCl}_{3}$ into oxychloride: 1) water and alcohol ionise hydroxyl groups and replace a $\mathrm{Cl}$ atom in $\mathrm{SbCl}_{3}$ to form $\left[\mathrm{Sb}(\mathrm{OH}) \mathrm{Cl}_{2}\right]$ monomer; as the degree of hydrolysis progresses, the monomer loses $\mathrm{H}$ and $\mathrm{Cl}$ to form $\mathrm{SbOCl}, \mathrm{Sb}_{3} \mathrm{O}_{4} \mathrm{Cl}$, and $\mathrm{Sb}_{4} \mathrm{O}_{5} \mathrm{Cl}_{2} ; 2$ ) $\mathrm{Sb}$ directly forms $[\mathrm{Sb}-\mathrm{OH}]$ monomer with $\mathrm{OH}$ ionised by water and alcohol, and $\mathrm{Cl}$ replaces the $\mathrm{H}$ on the $[\mathrm{Sb}-\mathrm{OH}]$ hydroxyl group in the monomer and directly forms $\mathrm{SbOCl}, \mathrm{Sb}_{3} \mathrm{O}_{4} \mathrm{Cl}$, and $\mathrm{Sb}_{4} \mathrm{O}_{5} \mathrm{Cl}_{2}$.
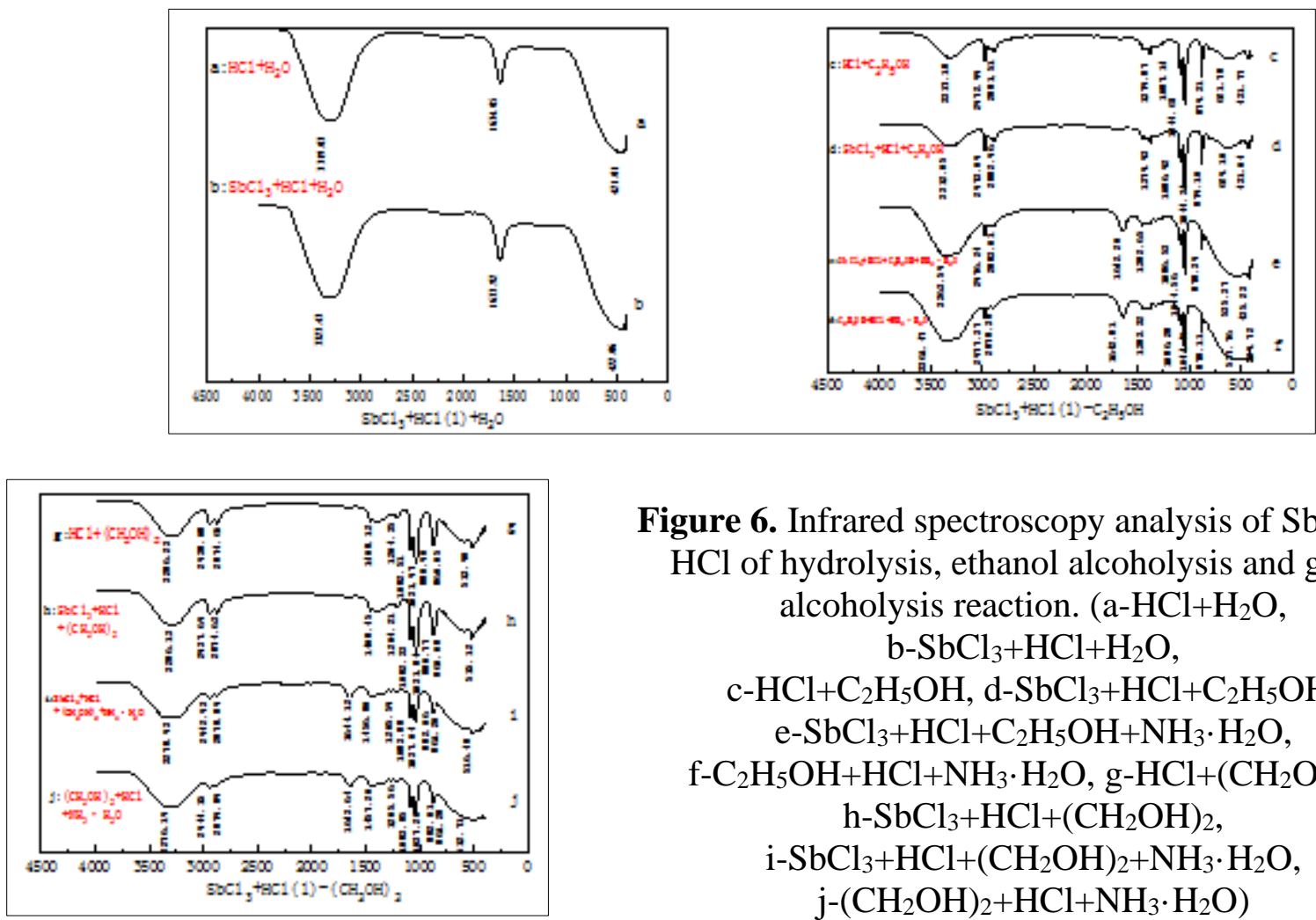

Figure 6. Infrared spectroscopy analysis of $\mathrm{SbCl}_{3}$ and $\mathrm{HCl}$ of hydrolysis, ethanol alcoholysis and glycol alcoholysis reaction. $\left(\mathrm{a}-\mathrm{HCl}+\mathrm{H}_{2} \mathrm{O}\right.$, $\mathrm{b}-\mathrm{SbCl}_{3}+\mathrm{HCl}+\mathrm{H}_{2} \mathrm{O}$, $\mathrm{c}-\mathrm{HCl}+\mathrm{C}_{2} \mathrm{H}_{5} \mathrm{OH}, \mathrm{d}-\mathrm{SbCl}_{3}+\mathrm{HCl}+\mathrm{C}_{2} \mathrm{H}_{5} \mathrm{OH}$, $\mathrm{e}-\mathrm{SbCl}_{3}+\mathrm{HCl}+\mathrm{C}_{2} \mathrm{H}_{5} \mathrm{OH}+\mathrm{NH}_{3} \cdot \mathrm{H}_{2} \mathrm{O}$,

$\mathrm{f}-\mathrm{C}_{2} \mathrm{H}_{5} \mathrm{OH}+\mathrm{HCl}+\mathrm{NH}_{3} \cdot \mathrm{H}_{2} \mathrm{O}, \mathrm{g}-\mathrm{HCl}+\left(\mathrm{CH}_{2} \mathrm{OH}\right)_{2}$, $\mathrm{h}-\mathrm{SbCl}_{3}+\mathrm{HCl}+\left(\mathrm{CH}_{2} \mathrm{OH}\right)_{2}$, i- $\mathrm{SbCl}_{3}+\mathrm{HCl}+\left(\mathrm{CH}_{2} \mathrm{OH}\right)_{2}+\mathrm{NH}_{3} \cdot \mathrm{H}_{2} \mathrm{O}$, $\left.\mathrm{j}-\left(\mathrm{CH}_{2} \mathrm{OH}\right)_{2}+\mathrm{HCl}+\mathrm{NH}_{3} \cdot \mathrm{H}_{2} \mathrm{O}\right)$ 


\section{Conclusions}

(1) The density functional method was used to calculate the electronic properties of $\mathrm{SbCl}_{3}, \mathrm{SbOCl}$, $\mathrm{Sb}_{3} \mathrm{O}_{4} \mathrm{Cl}$, and $\mathrm{Sb}_{4} \mathrm{O}_{5} \mathrm{Cl}_{2}$ unit cells using analyses of unit cell structure, unit cell energy, energy band, total density of states, partial density of states, overlap populations, formal charges, and covalent bond properties of $\mathrm{SbCl}_{3}, \mathrm{SbOCl}, \mathrm{Sb}_{3} \mathrm{O}_{4} \mathrm{Cl}$, and $\mathrm{Sb}_{4} \mathrm{O}_{5} \mathrm{Cl}_{2}$ in their respective unit cells. This was combined with information from analysis of infrared spectroscopic data for hydrolysis reactions leading to antimony oxychloride by atom transfer. There are two main ways to hydrolyse $\mathrm{SbCl}_{3}$ into oxychloride: the hydroxyl groups in water and alcohol are ionised to replace one $\mathrm{Cl}$ atom in $\mathrm{SbCl}_{3}$ and form a $\left[\mathrm{Sb}(\mathrm{OH}) \mathrm{Cl}_{2}\right]$ monomer. During further hydrolysis, $\mathrm{H}$ and $\mathrm{Cl}$ atoms are removed. Alternatively, $\mathrm{SbOCl}$, $\mathrm{Sb}_{3} \mathrm{O}_{4} \mathrm{Cl}$, and $\mathrm{Sb}_{4} \mathrm{O}_{5} \mathrm{Cl}_{2}$ or $\mathrm{Sb}$ atoms are formed directly from [Sb-OH] monomers with $\mathrm{OH}$ ionised by water or alcohol. $\mathrm{Cl}$ atoms replace the $\mathrm{H}$ atoms on the hydroxyl groups in $[\mathrm{Sb}-\mathrm{OH}]$ monomers to form $\mathrm{SbOCl}, \mathrm{Sb}_{3} \mathrm{O}_{4} \mathrm{Cl}$, and $\mathrm{Sb}_{4} \mathrm{O}_{5} \mathrm{Cl}_{2}$ directly.

(2) Infrared spectroscopy indicated that with $\mathrm{SbCl}_{3}$ in the water, ethanol, and ethylene glycol systems, the water hydroxyl group and alcohol hydroxyl group exhibited redshift and blueshift in the infrared spectra; the hydroxyl band at high frequency changed because the chlorine atom replaced the hydrogen atom, and the electron density increased. The force constant $\mathrm{k}$ increased, an inductive effect occurred, the group frequency shifted to higher wavenumber, the infrared spectrum was redshift; since the polarity of the $-\mathrm{OCl}$ bond is weaker than that of the - $\mathrm{OH}$ bond, the hydroxyl vibration shifted to lower frequency. A blueshift occurred, which indicates that the hydrogen atom on - $\mathrm{OH}$ was replaced by a chlorine atom; this is consistent with the calculated results on the strength of the covalent bond between chlorine and oxygen, which confirms the results of the density functional method.

Acknowledgements:This paper has been financially supported by the National Natural Science Foundation of China (No.U1802251), Jiangxi Provincial Department of Science and Technology Project(NO.20212AEI91003),Jiangxi Provincial Department of Education Science and Technology Project (No. GJJ180466).Special thanks also go to staff at Jiangxi Copper Corporation Limited Guixi Smelter for providing the Copper anode slime materials used in this study.

\section{References}

1.YANG H-Y, LI X-J, TONG L-L, et al., Process mineralogy of high lead copper anode slime [J]. The Chinese Journal of Nonferrous Metals, 2014, 24(01): 269-278.

2.WANG X-W, CHEN Q-Y, YIN Z-L, et al., Identification of arsenato antimonates in copper anode slimes[J]. Hydrometallurgy, 2006, 84(3-4): 211-217.

3.ZHONG S-P, WANG J, ZHANG H-R, et al., Extraction Technology of Copper Anode Slime by Caldo Furnace Method[M], 2019(Metallurgical Industry Press).

4.HOU H-F., Complex Recovery ofNon-ferrous, Rare and Noble Metals from Copper Anode Slime [J]. SHANGHAI NONFERROUS METALS, 2000(02): 88-93.

5.KONG X-F, DENG J-H., Research Status of Copper Anode Sludge Treatment [J]. World Nonferrous Metals, 2019(19): 169+171.

6.ZHANG B-Y, WANG J-K., Production practice of copper anode slime treatment by dressingmetallurgy combination method[J]. China Nonferrous Metallurgy, 2007(03): 59-62.

7.JIN Z-N, MA Z-Y, YANG H-Y, et al., Behaviors of Precious and Base Metals in Process of Copper Anode Slime Hydrometallurgical Treatment [J]. Journal of Northeastern University(Natural Science), 2015, 36(09): 1305-1309.

8.YE L-G, ZHEN O-Y, CHEN Y-M, et al., Selective separation of antimony from a Sb-Fe mixed solution by hydrolysis and application in the hydrometallurgical process of antimony extraction[J]. Separation and Purification Technology, 2019:115753.

9.ZHENG Y-J, TENG H, BAI M., Preparation of high-purity antimony oxychloride from high-arsenic refined bismuth dust[J]. Journal of Central South University: Science and Technology, 2011,(6): 1549-1554. 
10.ZHANG D-M, XIAO S-W., Ostwald rule and the polymorphous control of antimony white prepared by wet method[J]. Journal of Central South University of Technology(Natural Science), 2000,(2):121123.

11.LING M, ZHANG S-G, PAN D.-A., et al., Antimony recovery from $\mathrm{SbCl}_{5}$ acid solution by hydrolysis and aging[J]. Rare Metals, 2015,34(06):436-439.

12.ZHENG G-Q., ZHI B., CHEN J-Z., Hydrolysis of antimony pentachloride[J], The Chinese Journal of Nonferrous Metals, 2006, (9):1628-1633.

13.A. KOLIADIMA, A. HENGLEIN, E. MATIJEVIC. Colloidal hydrolysis products of $\mathrm{SbCl}_{3}$ in acidic solutions[J]. Colloid and Polymer Science, 1997, Vol.275(NO.10):972-978.

14.A.E. PANASENKO, L. A. ZEMUKHOVA, L. N. IGNATEVA, et al., Phase composition of antimony(III) oxide samples of different origin[J]. Inorganic Materials, 2009, Vol.45(No.4):402-408.

15.U. YUCELIK ÖZER, R. F. BOGUCKI. Equilibrium studies of antimony(III) chelates in aqueous solution[J].Journal of Inorganic and Nuclear Chemistry, 1971,Vol.33(No.12):4143-4153.

16.NEELAM YADAV, MEENA NAGER, RAKESH BOHRA, New sol-gel precursors for binary oxides of antimony, $\mathrm{Sb}_{2} \mathrm{O}_{3}$ (senarmonite) and $\alpha-\mathrm{Sb}_{2} \mathrm{O}_{4}$ : synthesis and characterization of some ketoximate modified antimony(III) alkoxides[J].Journal of Sol-Gel Science and Technology, 2010, Vol.54(No.1):119-128.

17.TIAN Q-H., XIN Y-T.Y., YANG L., et al. Theoretical simulation and experimental study of hydrolysis separation of $\mathrm{SbCl}_{3}$ in complexation-precipitation system[J]. Transactions of Nonferrous Metals Society of China, 2016, 26(10):2746-2753.

18.DU X-L. Research on the hydrolysis equilibrium of antimony trichloride in the $\mathrm{Sb}^{3+}-\mathrm{Cl}^{-}-\mathrm{H}_{2} \mathrm{O}$ system[J]. China Nonferrous Metallurgy, 2012, (5).

19.ZHENG G-Q, HUANG R-B, PAN Y, et al., Phases of antimony trichloride solution containing fluorine neutralization-hydrolysis products[J]. The Chinese Journal of Nonferrous Metals, 2005, 15(8): 1278-1282.

20.CLARK S J., SEGALLII M D., PICKARDII C J., et al., First principles methods using CASTEP[J]. Zeitschrift für Kristallographie, 2005, 220(5-6).

21.MILMAN V., REFSON K., CLARK S J., et al., Electron and vibrational spectroscopies using DFT, plane waves and pseudopotentials: CASTEP implementation[J]. Journal of Molecular Structure THEOCHEM, 2010, 954(1):22-35.

22.NI Z, GUO X , LIU X., et al., Understanding the magnetic structural transition in all-d-metal Heusler alloy $\mathrm{Mn}_{2} \mathrm{Ni}_{1.25} \mathrm{Co}_{0.25} \mathrm{Ti}_{0.5}[\mathrm{~J}]$. Journal of Alloys and Compounds, 2019, 775:427-434.

23.FRANCISCO C , FERNANDEZ ANA MARIA, TIMON VICENTE, et al., Becquerelite mineral phase: crystal structure and thermodynamic and mechanical stability by using periodic DFT[J]. RSC Advances, 2018, 8(43):24599-24616.

24.DENG Y., EAMES C., NGUYEN L H B., et al., Crystal structures, local atomic environments and ion diffusion mechanisms of scandium-substituted NASICON solid electrolytes[J]. Chemistry of Materials, 2018:acs.chemmater.7b05237.

25.XIAO X., XING C., HE G., et al., Solvothermal synthesis of novel hierarchical Bi4O5I2 nanoflakes with highly visible light photocatalytic performance for the degradation of 4-tert-butylphenol[J]. Applied Catalysis B: Environmental, 2014, 148-149:154-163.

26.YUAN S, SUN Z, REN W, et al., First principles study of the magnetic properties and charge transfer of Ni-doped $\mathrm{BiFeO}_{3}[\mathrm{~J}]$. Journal of Magnetism \& Magnetic Materials, 2017, 449:S0304885317307461. 27.ZHANG S Y, HU C L, LI P X, et al., Syntheses, crystal structures and properties of new lead(II) or bismuth(III) selenites and tellurite[J]. Dalton Transactions, 2012, 41(31):9532-9542.

28.JIANG H Y., LI P., LIU G., et al., Synthesis and photocatalytic properties of metastable $\beta-\mathrm{Bi}_{2} \mathrm{O}_{3}$ stabilized by surface-coordination effects[J]. Journal of Materials Chemistry A, 2015, 3.

29.WU C., LU P., YU Z., et al., Structural and Electronic Properties of Neutral Clusters A112X (X = P, $\mathrm{As}, \mathrm{Sb}$, and $\mathrm{Bi}$ ) and Their Cations[J]. Journal of Computational and Theoretical Nanoscience, 2013, 10(5):1055-1060. 
30.ZHANG X.-Y., ZHENG B.-J., GUO B., et al., First Principles Study on Electronic Structure and Corrosion Resistance of Fe-N-Cr[J]. Materials Reports, 2016, 30(18):155-158.

31.WANG M.-J., LI C.-F., WEN P., et al., The bond characters and phase stability effects of Cr Mo and $\mathrm{Ni}$ in bulk -Fe(C)[J]. Acta Physica Sinica, 2016, 65(3):246-255.

32.ZHANG P., ZHAO Q.-C., LIU J.-J., et al., Research on inhibitors and hindered groups in ultra-deep hydrodesulfurization based on density functional theory[J]. Catalysis Today, 2018:170-178.

33.XUE J.-X., ZHANG R.-G., LIU Y.-P., et al., The alloying of Ti, C, N in bulk $\alpha$-Fe and their effects on bond characters[J]. Acta Physica Sinica, 2012, (12):427-434.

34.WEN P., LI C.-F., ZHAO Y., et al., First principles calculation of occupancy, bonding characteristics and alloying effect of Cr, Mo, Ni in bulk $\alpha-\mathrm{Fe}(\mathrm{C})[\mathrm{J}]$. Acta Physica Sinica, 2014, (19):288-295.

35.YANG J.-M., ZHANG H.-M., WANG XU, et al., The Relationships and Differences Between the Infrared Spectrometry and Raman Spectrometry[J]. Physics and Engineering, 2014, 24(4):26-29.

36.WANG J.-Z., WANG T., How to Interpret Infrared (IR) Spectra[J]. University Chemistry, 2016, 31(6):90-97. DOI:10.3866/PKU.DXHX201504001.

37.HU H.-L., Raman Spectroscopy Analysis and Concentration Correlation Study of Ethanol-Water Solution[D]. Jiangsu: Nanjing University of Science and Technology 2012. DOI:10.7666/d.y2062091.

38.YUAN B., DOU X.-M., Near-Infrared Spectral Studies of Hydrogen-Bond in Water-Methanol Mixtures[J]. Spectroscopy and Spectral Analysis, 2004, 24(11):1319-1322.

DOI:10.3321/j.issn:1000-0593.2004.11.011.

39.XIE Y., YI J., ZHANG S., et al., Study on Ternary Mixtures of Water, Acetic Acid and Ethanol by Near Infrared Spectroscopy[J]. Chinese Journal of Spectroscopy Laboratory, 2003, 20(5):643-646.

DOI:10.3969/j.issn.1004-8138.2003.05.002.

40.ZHU C.-G., WANG F.-W., XU M., et al., Synthesis of Metal Alkoxide Complex and Nano-NiFe ${ }_{2} \mathrm{O}_{4}$ in $\mathrm{HOCH}_{2} \mathrm{CH}_{2} \mathrm{OH}$ Solution[J]. Chinese Journal of Inorganic Chemistry, 2009, 25(7):1177-1181.

DOI:10.3321/j.issn:1001-4861.2009.07.007.

41.NEELAM YADAV, MEENA NAGAR, RAKESH BOHRA, New sol-gel precursors for binary oxides of antimony, $\mathrm{Sb}_{2} \mathrm{O}_{3}$ (senarmonite) and $\alpha-\mathrm{Sb}_{2} \mathrm{O}_{4}$ : synthesis and characterization of some ketoximate modified antimony(III) alkoxides[J].Journal of Sol-Gel Science and Technology, 2010, Vol.54(No.1):119-128.

Manuscript received: 8.07 .2021 